\title{
A comparison of the gene expression profiles and pathway network analyses after treatment of Prostate cancer cell lines with different Ganoderma lucidum based extracts.
}

\author{
Authors: Chi H.J. Kao', Karen S. Bishop ${ }^{2}$, Dug Yeo Han ${ }^{3}$, Pamela M. Murray², \\ Marcus P. Glucina ${ }^{4}$, Gareth J. Marlow ${ }^{3}$, and Lynnette R. Ferguson ${ }^{1,2,3^{*}}$
}

\begin{abstract}
${ }^{1}$ Discipline of Nutrition, Faculty of Medical and Health Sciences, The University of Auckland, Auckland 1142, New Zealand; ${ }^{2}$ Auckland Cancer Society Research Centre, Faculty of Medical and Health Sciences, The University of Auckland, Auckland 1142, New Zealand; ${ }^{3}$ Nutrigenomics New Zealand, The University of Auckland, Auckland 1142, New Zealand; ${ }^{4}$ NZFOCUS (NZ) Ltd., Auckland, New Zealand
\end{abstract}

*Corresponding author: Lynnette R. Ferguson Discipline of Nutrition, Faculty of Medical and Health Sciences, The University of Auckland, Auckland 1142, New Zealand

Submission date: November 13, 2013; Acceptance date: May 17, 2014; Publication date: May 23, 2014

\begin{abstract}
Background: Ganoderma lucidum is a type of fungus commonly consumed in Asia for the promotion of health and longevity. The observed biological activity of G. lucidum includes anti-cancer and anti-inflammatory effects which may be useful in the treatment and prevention of cancer and other chronic diseases. G. lucidum grows under conditions which range from tropical to temperate and has a different physiology depending on the geographical region in which it is grown. For this reason, the health benefits may vary depending on the form of G. lucidum and the environmental conditions to which it was exposed. This led us to investigate the effect of wildly grown G. lucidum, from the Himalayan region versus other commercially available G. lucidum products, on two human cancer cell lines.
\end{abstract}

Methods: Extraction of the bioactive components found in G. lucidum is essential, as the fungus is tough and indigestible. Four different Ganoderma extracts were prepared. Thereafter, the extracts were tested on two human prostate cancer cell lines, and the $\mathrm{IC}_{50} \mathrm{~S}$ were determined. This was followed by the use of Affymetrix GeneChip ${ }^{\circledR}$ PrimeView ${ }^{\text {TM }}$ Human Gene Expression Arrays to identify the changes in gene expression due to the treatment of prostate cancer cell lines (PC3 and DU145) with Ganoderma extracts. Several key genes identified with Affymetrix analysis were validated using RT-PCR.

Results and Discussion: We found that all the Ganoderma extracts showed growth inhibition in the cancer cell lines tested. Using Affymetrix microarray analysis, we identified four main biologically active pathways: cell cycle control/apoptosis, cell-cell adhesion, DNA repair, and inflammatory /immune response, where activity was influenced 
by the Ganoderma extracts used. Using RT-PCR, we tested ten genes associated with all four pathways. The RT-PCR results supported our findings in the Affymetrix analysis, i.e. that G. lucidum extracts have an anti-inflammatory and cell cycle effect and therefore may have long term health benefits. These effects were specific to the extract tested.

Key Words: Ganoderma lucidum, PC3, DU145, gene expression, Affymetrix, pathways, RT-PCR

\section{BACKGROUND}

Ganoderma lucidum (G. lucidum), commonly called Lingzhi in China, Reishi or Sachitake in Japan, and Youngzhi in Korea, is a large, dark fungus with a glossy exterior and a woody texture [1]. G. lucidum grows under a range of conditions and distinct forms grow in diverse geographical regions including North America, Asia, and sub-Asia continents [2]. This fungus generally occurs in two growth forms: one found in North America, which is sessile and large with a reduced stalk; whilst the other is smaller and has a long, narrow stalk [2]. The latter is found mainly in the tropics and is the form used in this study.

Owing to the numerous health benefits associated with the consumption of G. lucidum, there is a high demand for this fungus in parts of Asia. In order to meet growing demands, cultivation has become a major industry. Artificial cultivation of G. lucidum has been achieved using substrates such as grain, sawdust, wood logs, and cork residues [2]. It remains to be seen whether the growth conditions influence the reported health properties of this fungus.

For centuries G. lucidum has been used for the general promotion of health and longevity in Asian countries [1, 3]. It has been recorded as having numerous pharmacological effects, such as immuno-modulating, anti-inflammatory, analgesic, chemopreventive, anti-tumour, radio-protective, anti-viral, anti-oxidative and radical-scavenging, and anti-aging effects [4]. Studies have shown that G. lucidum can significantly improve a number of health and gerontology-related problems $[2,4,5]$.

There are two main bioactive ingredients that are likely to contribute to the anti-cancer properties of G. lucidum: polysaccharides, which are extracted using a water based method, and triterpenes, which can be extracted using an ethanol based method [6].

Both G. lucidum polysaccharides and triterpenes, in the form of Ganoderic acids, have been shown to modulate and improve immune function in human and mouse models [7, 8, 9], due to increased survival of immune cells related to both innate- and adaptive-immunity $[10,11]$. These extracts can also be used to enhance anti-tumour immune response by promoting the activity of natural killer cells, cytotoxic T-lymphocytes [12], as well as boost antigen presentation, which is crucial for viral and cancer immunity [13]. Extracts from $G$. lucidum have shown carcinostatic effects in a wide variety of cancer cell lines, including those of the breast, pancreas, lung, colon, skin, and prostate [2]. These biologically active components can affect various biological pathways associated with the survival, progression, and metastasis of tumours. The identification of the bioactive components and their associated anti-cancer activities in G. lucidum present Ganoderma as a potential therapeutic agent for the treatment and prevention of cancer.

In addition to its potential use as an anti-cancer agent, G. lucidum may also be beneficial in conjunction with other anti-cancer therapies. One of the main drawbacks of a number of different anti-cancer therapies is the associated side-effects. Radiotherapy, used 
in the treatment of some cancers, can cause damage to adjacent, non-target, healthy tissues. G. lucidum, as well as having carcinostatic effects, has shown radio-protective effects in normal cells via the prevention of DNA damage induced by radiation [14]. In addition, $G$. lucidum has been shown to enhance the recovery of cellular immune-competence from gamma-irradiation $[15,16]$. The observed radio-protective effects both in in vitro and animal studies suggest that $G$. lucidum may reduce the adverse side-effects caused by radiotherapy. G. lucidum also has the potential to help reduce the toxicity and undesirable side-effects from common cancer chemotherapies, such as Cisplatin [17], and could therefore play a major role in combination therapy with cancer treatments to not only reduce anti-oxidant effects but to act synergistically as well [17, 18]. G. lucidum, when used in combination with various well-established cancer therapies, is shown to reduce the adverse side effects associated with anti-cancer therapies [19]. The fact that G. lucidum is carcinostatic and lacks any observable side-effects [19] makes it an ideal candidate to be used as a natural remedy for the treatment of various forms of cancer, including cancer of the lung, breast, colon, and prostate.

In this study, we have prepared several Ganoderma extracts and used a comprehensive transcriptomic analysis (Affymetrix GeneChip ${ }^{\circledR}$ PrimeView ${ }^{\mathrm{TM}}$ Human Gene Expression Arrays) to identify the critical genes and pathways associated with the biologically active ingredients of G. lucidum. Analyses of these changes in gene expression have identified several major biological pathways associated with the potential health benefits of the Ganoderma extracts including anti-cancer and anti-inflammatory effects. In addition, we use real time - polymerase chain reaction (RT-PCR), to confirm some of our findings in the Affymetrix gene expression analysis.

\section{METHODS:}

Materials: The dried fruiting bodies of wild G. lucidum were provided by NZFOCUS (NZ) Ltd. All chemicals and reagents were from Sigma-Aldrich Co., unless indicated.

Preparation of $\boldsymbol{G}$. lucidum extracts: A total of four Ganoderma extracts were tested in this study; these were: Ganoderma water extract, Ganoderma ethanol extract, GanoPoly® ${ }^{+}$ (ENCORE International ltd.), and Ganoderma spore oil (Xianzhilou Biological Science \& Technology Co., Ltd.) extract. Their properties and extraction processes are described below:

Ganoderma water extracts: Hot water extraction of $G$. lucidum is the most widely employed traditional method for extracting the active ingredients of G. lucidum [2]. Ten grams of G. lucidum were cut into 0.5 to $1 \mathrm{~cm}$ pieces and extracted using the water-based method as outlined by Lu et al. [20].

Ganoderma ethanol extracts: Studies have shown that extraction of G. lucidum with an ethanol solvent yielded the highest amount of triterpenes, including Ganoderic acids [21, 22]. Ten grams of G. lucidum were cut into 0.5 to $1 \mathrm{~cm}$ pieces and extracted using an ethanol based method as outlined by Lakshmi et al. [23].

Ganopoly® $\mathbf{C}^{+}$, hereafter abbreviated as Ganopoly, is a commercially available health supplement. Each capsule contained $500 \mathrm{mg}$ of Ganopoly powder concentrated from $27.5 \mathrm{~g}$ 
of dry G. lucidum [8, 9]. The Ganopoly powder was dissolved in Dimethyl Sulfoxide (DMSO) to give a concentration of $110.7 \mathrm{mg} / \mathrm{ml}$ (Ganopoly powder). Thus $110.7 \mathrm{mg} / \mathrm{ml}$ Ganopoly solution was equivalent to $6088 \mathrm{mg} / \mathrm{ml}$ of dry G. lucidum fruit.

Ganoderma spore oil: Spore oil softgel is marketed in China as an over-the-counter product for general health improvement. According to the manufacturer, each soft gel pill contained $100 \mathrm{mg}$ of Ganoderma spore oil. The spore oil was dissolved in DMSO to give a concentration of $0.2 \mathrm{mg} / \mathrm{ml}$.

Azathioprine: (Sigma Chemical Company) was used as a positive control for assessing growth inhibitory potential of the Ganoderma extracts. Azathioprine is a known drug used for the treatment of childhood acute leukaemia which acts by suppressing cell proliferation via inhibition of DNA synthesis [24, 25].

Cell lines: Human prostate cancer (PCa) cell lines PC3 and DU145 were provided by the Auckland Cancer Society Research Centre. Both cell lines were grown in media consisting of Minimum Eagle Media $+10 \%$ Fetal Calf Serum $+1 \%$ of Penicillin/Streptomycin / Glutamine. The cells were grown in $25 \mathrm{ml}$ Becton Dickinson Falcon $^{\mathrm{TM}}$ cell culture flasks (BD Biosciences) at $37^{\circ} \mathrm{C}$ with $5 \% \mathrm{CO}_{2}$.

Growth inhibitory assay

The cells were harvested when they reached $90 \%$ confluence. All cell lines were seeded at a cell density of 2000 cells/well in the experimental 96-well plates and incubated overnight at $37^{\circ} \mathrm{C}$ with $5 \% \mathrm{CO}_{2}$ before treating with the extracts. The cells were incubated under the same condition for four doubling cycles. Growth inhibition was measured using the Sulforhodamine B based assay [26]. Using results from the growth inhibition assays, the optimal dosing range was determined. Standard curve analysis was performed using Sigma plot 11.0 (Systat Software Inc.) and the $\mathrm{IC}_{50}$ values of each extract in each cell line were determined using the standard curve.

RNA extraction: The cells were treated with the various extracts at the established $\mathrm{IC}_{50}$, and the RNA was isolated using an RNeasy Plus Mini Kit (QIAGEN). The concentration and purity of the RNA samples was assessed using a NanoDrop® ND-1000 Spectrophotometer (Thermo Fisher Scientific), as well as via Experion RNA Standard Sensitive (StdSen) Analysis (Bio-Rad) [27, 28]. The Affymetrix GeneChip ${ }^{\circledR}$ PrimeView ${ }^{\text {TM }}$ Human Gene Expression analysis required RNA samples with high integrity, namely an RNA quality index of $>8$.

Gene expression analysis: The Affymetrix GeneChip ${ }^{\circledR}$ PrimeView ${ }^{\mathrm{TM}}$ Human Gene Expression Arrays were used to measure the gene expression profile of selected cancer cell lines after treatment with various extracts. It is capable of measuring the expression of more than 20,000 genes using 530,000 probes covering 36,000 transcripts and their variants [29, 30]. A total of eight extracts (including positive and negative controls) were tested in PC3 and DU145. Three technical replicates were analysed per extract per cell line, resulting in a total of 48 samples submitted for Affymetrix analysis to be completed at the Ramaciotti Centre, University of New South Wales, Sydney, Australia. 
Affymetrix array data were analysed using the packages of 'affy' and 'limma' in R [31]. Correction for multiple testing was carried out using Benjamini-Hochberg false-discovery rate [31].

Pathway analysis: The data was selected based on statistical significance and strength of association with extracts. The process of data selection is summarized in Figure 1. The Affymetrix analysis generated raw absorbance data for the 530,000 probes used.

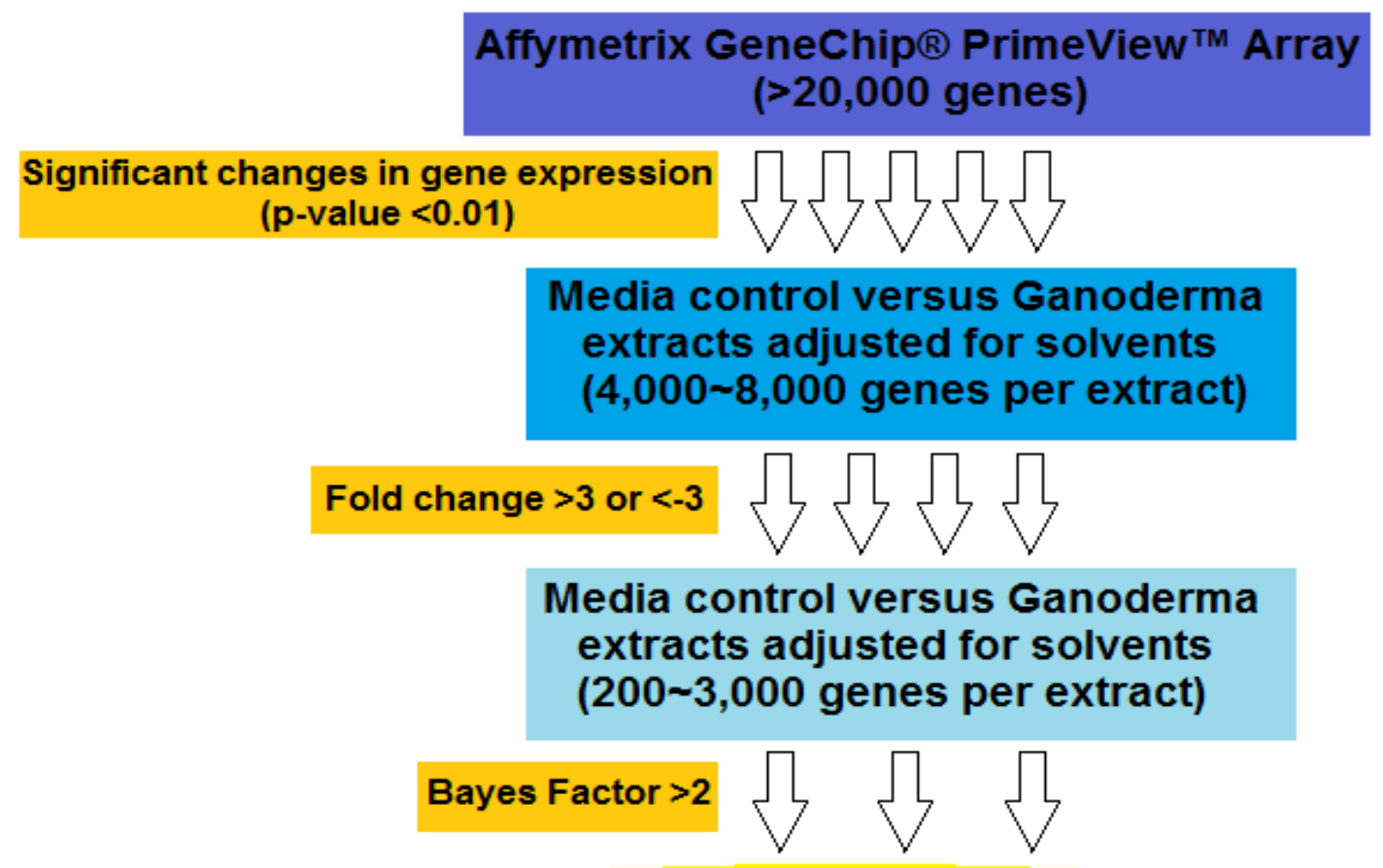

Search for significantly disturbed pathways

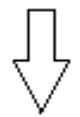

Figure 1. Overview of Affymetrix Genechip ${ }^{\circledR}$ PrimeView $^{\text {TM }}$ array data analysis. Data analysis process used to identify significant genes for GATHER pathway analysis utilizing the raw data generated by Affymetrix analysis. The fold change and p-values were calculated from raw data. Only genes with a fold change of three or greater and a p-value of less than 0.01 were selected. The selected genes were input into GATHER and a list of biologically active pathways was generated. GATHER = Gene Annotation Tool to Help Explain Relationships.

A p-value of 0.01 was chosen as the cut off point for statistical significance. Genes with a fold change of greater than three, regardless of whether they were up- or down-regulated, were selected for pathway analysis using Gene Annotation Tool to Help Explain Relationships (GATHER). The selected genes from each extract per cell line were submitted to GATHER separately to find Gene Ontology annotations. GATHER (http://gather.genome.duke.edu/) is a gene annotation tool which examines the relationships between genes. GATHER generates a list of biological pathways associated with the genes submitted, and ranks them based on Bayes factor. The Bayes factor represents the strength of association between the list of genes submitted and the biological pathway based on the 
Gene Ontology Database. The higher the Bayes factor value, the stronger the association [32].

RT-PCR: The RNA was converted to cDNA using a Quantitect Reverse Transcription Kit (QIAGEN). The genes of interest were amplified with relevant primers available from Invitrogen as shown in Table 1.

Table 1. List of selected genes and their respective RT-PCR assay IDs with target chromosome locations. For each RT-PCR assay, the closest probe (based on chromosome location) in the Affymetrix array analysis is also listed.

\begin{tabular}{|c|c|c|c|c|}
\hline & \multicolumn{2}{|c|}{ RT-PCR analysis } & \multicolumn{2}{|c|}{ Affymetrix array analysis } \\
\hline Gene & Assay ID & Chromosome location & Probe ID & $\begin{array}{l}\text { Chromosome } \\
\text { location }\end{array}$ \\
\hline$B R C A 1$ & Hs01556193_m1 & $\begin{array}{l}\text { Chr.17: } 41196312 \text { - } \\
41277500\end{array}$ & 11744317_x_at & $\begin{array}{l}\text { chr17:41196311- } \\
41277468\end{array}$ \\
\hline $\mathrm{CDH11}$ & Hs00901475_m1 & $\begin{array}{l}\text { Chr.16: } 64980683- \\
65155919\end{array}$ & 11749461_a_at & $\begin{array}{l}\text { chr16:64980684- } \\
65155930\end{array}$ \\
\hline$C D K N 3$ & Hs00193192_m1 & $\begin{array}{l}\text { Chr.14: } 54863673- \\
54886936\end{array}$ & 11730821_x_at & $\begin{array}{l}\text { chr14:54863672- } \\
54886936\end{array}$ \\
\hline COL11A1 & Hs01097664_m1 & $\begin{array}{l}\text { Chr.1: } 103342023 \text { - } \\
103574052\end{array}$ & 11733706_s_at & $\begin{array}{l}\text { chr1:103342028- } \\
103574052\end{array}$ \\
\hline IFITM1 & Hs00705137_s1 & $\begin{array}{l}\text { Chr.11: } 313991- \\
315272\end{array}$ & 11715670_a_at & $\begin{array}{l}\text { chr11:313526- } \\
315272\end{array}$ \\
\hline$I L 1 \alpha$ & Hs00174092_m1 & $\begin{array}{l}\text { Chr.2: } 113531492- \\
113542971\end{array}$ & 11725198_at & $\begin{array}{l}\text { chr2:113531501- } \\
113542971\end{array}$ \\
\hline IL24 & Hs01114274_m1 & $\begin{array}{l}\text { Chr.1: } 207070788- \\
207077484\end{array}$ & 11741775_a_at & $\begin{array}{l}\text { chr1:207070788- } \\
207077484\end{array}$ \\
\hline $\operatorname{IRF} 1$ & Hs00971960_m1 & $\begin{array}{l}\text { Chr.5: } 131817301- \\
131826465\end{array}$ & 11716733_at & $\begin{array}{l}\text { chr5:131816674- } \\
131826475\end{array}$ \\
\hline$M C M 7$ & Hs00428518_m1 & $\begin{array}{l}\text { Chr.7: } 99690404 \text { - } \\
99699427\end{array}$ & 11752905_a_at & $\begin{array}{l}\text { chr7:99690403- } \\
99698981\end{array}$ \\
\hline$R A D 51$ & Hs00153418_m1 & $\begin{array}{l}\text { Chr.15: } 40987327 \text { - } \\
41024356\end{array}$ & 11734841_a_at & $\begin{array}{l}\text { chr15:40987357- } \\
41024504\end{array}$ \\
\hline S100A9 & Hs00610058_m1 & $\begin{array}{l}\text { Chr.1: } 153330330 \text { - } \\
153333503\end{array}$ & 11716523_at & $\begin{array}{l}\text { chr1:153330329- } \\
153333503\end{array}$ \\
\hline
\end{tabular}

Glyceraldehyde 3-phosphate dehydrogenase (GAPDH) was used as a house-keeping gene for normalization of RNA expression. PCR was performed with a thermocycler (Applied Biosystems), and the amplified products were quantified using TaqMan® probes (Invitrogen). For each experimental setup, a standard curve was calculated with SDS2.3 software from three technical repeats. Two biological repeats were made. The relative expression was calculated using Microsoft Excel 2010 as fold change between extractstreated cell lines versus untreated controls, for comparison with Affymetrix results.

\section{RESULTS}

The growth-inhibitory properties and the resulting changes in gene expression levels of various extracts of G. lucidum on two human cancer cell lines were investigated. 
Growth inhibition of the prostate cancer cell lines: PC3 and DU145 are two cell line models of human PCa. Growth inhibition of the Ganoderma extracts and Azathioprine used to treat PC3 and DU145 were calculated from dose response curves and are shown in Table 2. All extracts showed positive dose-response curves supporting the claim that increased dosage of the extracts resulted in decreased cell survival.

Table 2. Growth inhibition of PC3 and DU145 versus concentration of Ganoderma extracts and Azathioprine.

\begin{tabular}{|l|l|l|}
\cline { 2 - 3 } \multicolumn{1}{c|}{} & \multicolumn{2}{l}{$\begin{array}{l}\text { Growth Inhibition } \\
(\mathbf{m g} / \mathbf{m l})\end{array}$} \\
\hline Extracts & PC3 $\mathbf{I C}_{\mathbf{5 0}}$ & $\begin{array}{l}\text { DU145 } \\
\text { IC }_{\mathbf{5 0}}\end{array}$ \\
\hline $\begin{array}{l}\text { Ganoderma water } \\
\text { extract }\end{array}$ & 7.95 & 12.44 \\
\hline $\begin{array}{l}\text { Ganoderma ethanol } \\
\text { extract }\end{array}$ & 0.217 & 0.132 \\
\hline Ganopoly & 0.222 & 0.334 \\
\hline Spore oil & $7.15 \mathrm{E}-04$ & $6.72 \mathrm{E}-04$ \\
\hline Azathioprine & $7.90 \mathrm{E}-04$ & $9.71 \mathrm{E}-04$ \\
\hline
\end{tabular}

Ganoderma spore oil extract had the lowest dosage required for 50\% growth inhibition, followed by Azathioprine, Ganoderma ethanol extract, and Ganopoly. Ganoderma water extract required the highest concentration to reach $\mathrm{IC}_{50}$. The same trend applied for Ganoderma ethanol extract, Ganopoly, and Ganoderma water extract at $\mathrm{IC}_{70}$ and $\mathrm{IC}_{90}$.

Biological pathways: A list of biological pathways, generated by GATHER, associated with Ganoderma ethanol extract and spore oil in PC3 and DU145 are shown in Table 3. A list of biological pathways associated with Ganoderma water extract and Ganopoly in PC3 and DU145 are shown in Table 4. Many of the identified pathways are interrelated. For example, the significant genes from the treatment of DU145 with Ganoderma ethanol extract were associated with pathways such as "regulation of cell cycle," "mitotic cell cycle," and "cell cycle checkpoints," which were all associated with cell cycle and proliferation. The biological pathways identified by GATHER were further grouped into associated biological functions. The Bayes factor was used to determine the statistical significance of the biological pathways. A Bayes factor of greater than two is considered statistically significant [32].

Ganoderma ethanol extract and spore oil extract treatment of PC3 and DU145 resulted in significant changes in the expression of genes associated with cell cycle and apoptosis, as shown in Table 3. A comparison of the two ethanol-based extracts across PC3 and DU145 cell lines showed that DU145 treated with Ganoderma ethanol has the greatest number of genes associated with cell cycle and apoptosis. Pathways associated with DNA repair, DNA replication, and cell-cell adhesions are also found to be associated with treatment with Ganoderma ethanol-based extracts. 
Table 3. A list of biological pathways associated with Ganoderma ethanol-based extracts in PC3 and DU145.

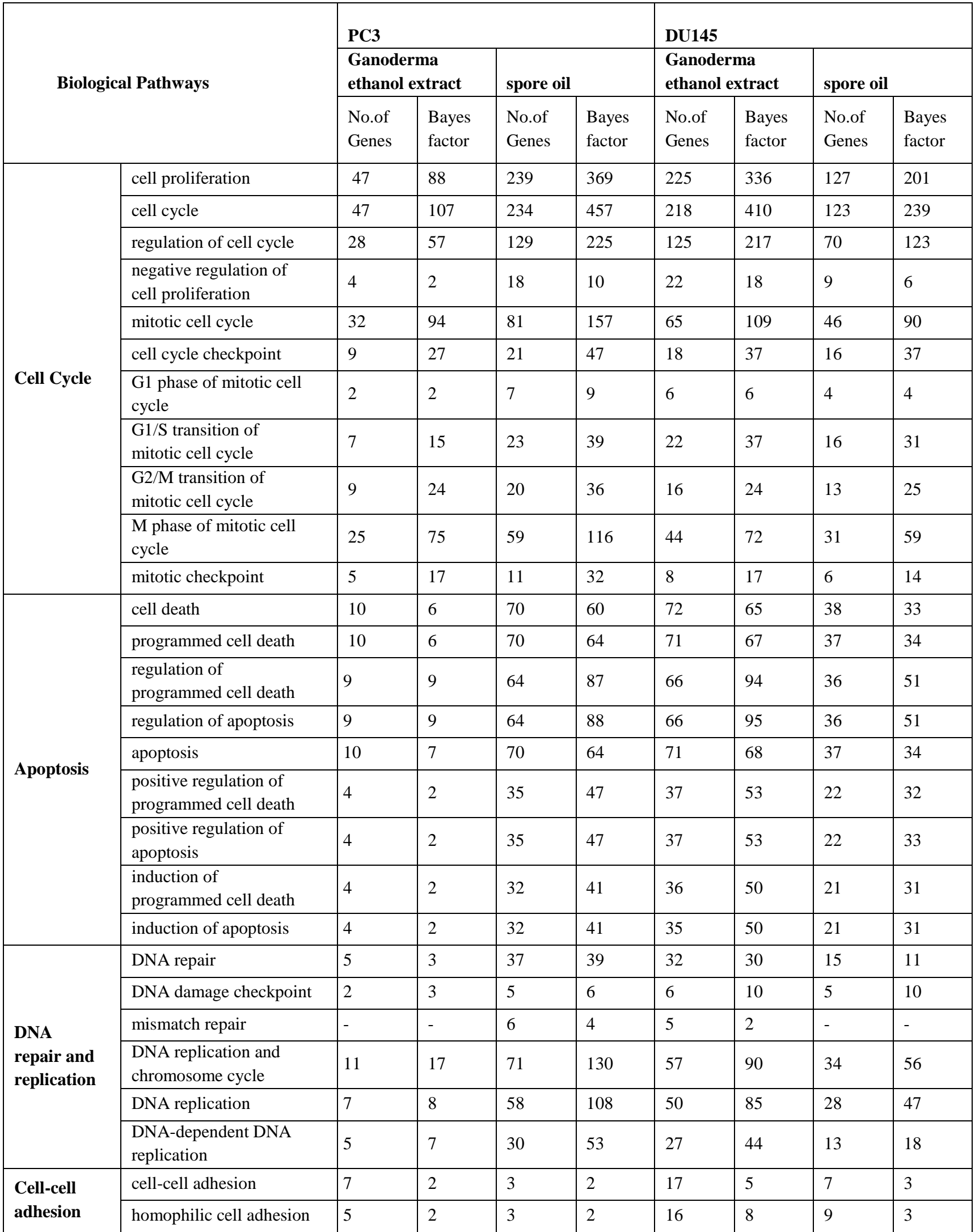

Both Ganoderma water extract and Ganopoly treatment of PC3 cells showed significant changes in gene expression associated with immune and inflammatory response, as shown in Table 4. Treatment with Ganopoly showed biological pathways associated with cell cycle, apoptosis, and angiogenesis in both PC3 and DU145 cell lines. 
Table 4. A list of biological pathways associated with Ganoderma water-based extracts in PC3 and DU145.

\begin{tabular}{|c|c|c|c|c|c|}
\hline \multirow{2}{*}{\multicolumn{2}{|c|}{ Biological Pathways }} & \multicolumn{2}{|c|}{ DU145 } & \multicolumn{2}{|c|}{ PC3 } \\
\hline & & \multirow[t]{2}{*}{$\begin{array}{l}\text { No. of } \\
\text { Genes }\end{array}$} & \multirow[t]{2}{*}{$\begin{array}{l}\text { Bayes } \\
\text { factor }\end{array}$} & \multirow[t]{2}{*}{$\begin{array}{l}\text { No. of } \\
\text { Genes }\end{array}$} & \multirow[t]{2}{*}{$\begin{array}{l}\text { Bayes } \\
\text { factor }\end{array}$} \\
\hline Ganoder & water extract & & & & \\
\hline \multirow{4}{*}{$\begin{array}{l}\text { Immune and } \\
\text { inflammatory } \\
\text { response }\end{array}$} & regulation of cellular process & 24 & 8 & 11 & 2 \\
\hline & response to biotic stimulus & 28 & 9 & 27 & 6 \\
\hline & immune response & 22 & 6 & 25 & 8 \\
\hline & defence response & 24 & 7 & 26 & 7 \\
\hline \multicolumn{6}{|l|}{ Ganopoly } \\
\hline \multirow{3}{*}{$\begin{array}{l}\text { Immune and } \\
\text { inflammatory } \\
\text { response }\end{array}$} & immune response & 19 & 26 & 25 & 42 \\
\hline & defence response & 19 & 24 & 25 & 39 \\
\hline & inflammatory response & 4 & 2 & 5 & 4 \\
\hline \multirow{7}{*}{ Cell Cycle } & cell proliferation & 21 & 25 & 18 & 17 \\
\hline & regulation of cell proliferation & 10 & 15 & 12 & 16 \\
\hline & cell cycle & 15 & 17 & 13 & 11 \\
\hline & regulation of cell cycle & 12 & 16 & 8 & 10 \\
\hline & cell cycle arrest & 4 & 7 & 4 & 6 \\
\hline & G2/M transition of mitotic cell cycle & 3 & 4 & 3 & 4 \\
\hline & G1/S transition of mitotic cell cycle & 3 & 4 & 3 & 3 \\
\hline \multirow{7}{*}{ Apoptosis } & cell death & 10 & 10 & 11 & 12 \\
\hline & programmed cell death & 10 & 10 & 11 & 12 \\
\hline & regulation of programmed cell death & 6 & 5 & 9 & 12 \\
\hline & regulation of apoptosis & 6 & 5 & 9 & 12 \\
\hline & apoptosis & 10 & 10 & 11 & 12 \\
\hline & $\begin{array}{l}\text { negative regulation of programmed cell } \\
\text { death }\end{array}$ & 3 & 2 & 5 & 7 \\
\hline & negative regulation of apoptosis & 3 & 2 & 5 & 7 \\
\hline \multirow{3}{*}{ Angiogenesis } & blood vessel development & 3 & 4 & 3 & 4 \\
\hline & blood vessel morphogenesis & 3 & 4 & 3 & 4 \\
\hline & angiogenesis & 3 & 4 & 3 & 4 \\
\hline
\end{tabular}

Four biologically active pathways have been identified as the result of Affymetrix analysis. The first is the cell cycle associated pathways. Genes associated with cell proliferation, cell cycle, and apoptosis were found to have significant changes in their expression levels after treatment with Ganoderma ethanol extract, spore oil, and Ganopoly in both PC3 and DU145 cell lines. Cell cycle control and apoptosis are two closely linked biological pathways [33, 34]. Expression of genes which promote or are associated with apoptosis are up-regulated, and expression of genes that inhibit apoptosis or are associated with reduced apoptosis are down-regulated. Genes associated with DNA repair and cell-cell adhesion were also found to be up-regulated with treatment of Ganoderma ethanol extract and spore oil in both cell lines. Genes associated with immune and inflammatory responses were found to be associated with treatment of Ganoderma water extract and Ganopoly in PC3 and DU145. Genes associated with angiogenesis were found to be associated with Ganopoly treatment only. 
Key genes: We have identified several key genes based on gene expression levels. Their significance to biological pathways associated with inflammation and $\mathrm{PCa}$ is supported by the literatures. Genes include: Cyclin-dependent kinase inhibitor 3 (CDKN3), RAD51, Cadherin 11, type 2 (CDH11), Collagen, type XI, alpha 1 (COL11A1), and Breast Cancer type 1 (BRCAl) in Ganoderma ethanol extract and Ganoderma spore oil extract, and the gene expression levels of S100 calcium binding protein A9 (S100A9), interferon induced transmembrane protein 1 (IFITM1), interleukin 24 (IL24), interleukin 1-alpha (IL1 $\alpha$ ), and interferon regulatory factor 1 (IRF1) in Ganoderma water extract and Ganopoly in PC3 and DU145 cell line.

Figure 2 shows a list of genes with significant changes in their expression levels after cell culture treatment with Ganoderma ethanol extract and spore oil extract.

Fold changes were calculated by carrying out a comparison between the extracts and media control, adjusted for their respective solvents (DMSO for spore oil and ethanol for Ganoderma ethanol extract). Only sample-treatment combinations with statistically significant adjusted $\mathrm{p}$-values $(\mathrm{p}<0.05)$ are shown. Empty blocks represent sampletreatment combinations with non-significant changes in gene expression.

\begin{tabular}{|c|c|c|c|c|c|c|c|c|c|c|c|c|}
\hline \multirow{3}{*}{ Gene Symbol } & \multirow{3}{*}{ GeneTitle } & \multirow{3}{*}{$\begin{array}{c}\text { Chromosome } \\
\text { Location }\end{array}$} & \multirow{3}{*}{ ProbesetID } & \multicolumn{4}{|c|}{$\mathrm{PC} 3$} & \multicolumn{4}{|c|}{ DU145 } & \multirow{3}{*}{ Gene Ontology } \\
\hline & & & & \multicolumn{2}{|c|}{ Spore oil } & \multicolumn{2}{|c|}{ Ganoderma ethanol extract } & \multicolumn{2}{|c|}{ Spore oil } & \multicolumn{2}{|c|}{ Ganoderma ethanol extract } & \\
\hline & & & & Fold Change & Adj. p-value & \begin{tabular}{|l|} 
Fold Change \\
\end{tabular} & Adj.p-value & \begin{tabular}{|l|} 
Fold Change \\
\end{tabular} & Adj.p-value & \begin{tabular}{|l|} 
Fold Change \\
\end{tabular} & Adj.p-value & \\
\hline \multirow{3}{*}{ BRCA1 } & \multirow{3}{*}{$\begin{array}{c}\text { breast cancer 1, } \\
\text { early onset }\end{array}$} & \multirow{3}{*}{ chr17q21 } & 11735584 x at at & 1.92 & $1.62 \mathrm{E}-03$ & 2.36 & $1.23 \mathrm{E}-05$ & 1.48 & $1.63 \mathrm{E}-04$ & 1.79 & $4.20 \mathrm{E}-04$ & \multirow{3}{*}{$\begin{array}{l}\text { Cell Cycle / } \\
\text { regulation of } \\
\text { apoptosis }\end{array}$} \\
\hline & & & 11744317_x_at & 2.34 & $7.07 E-04$ & 3.19 & $9.75 \mathrm{E}-08$ & 1.83 & $4.90 \mathrm{E}-04$ & 1.79 & $4.20 \mathrm{E}-04$ & \\
\hline & & & 11750373_a_at & 1.75 & $5.03 \mathrm{E}-03$ & 1.94 & $4.29 \mathrm{E}-04$ & - & - & 1.79 & $4.20 E-04$ & \\
\hline \multirow{2}{*}{$\mathrm{CDH} 11$} & \multirow{2}{*}{ cadherin 11 , type 2} & \multirow{2}{*}{ chr16q22.1 } & 11742873_a_at & 2.61 & $1.47 \mathrm{E}-03$ & 3.60 & $1.14 \mathrm{E}-07$ & - & - & - & - & \multirow{2}{*}{$\begin{array}{c}\text { Cell Cycle / } \\
\text { homophilic cell }\end{array}$} \\
\hline & & & 11749461_a_at & 7.97 & $9.78 E-07$ & 34.80 & $1.53 \mathrm{E}-11$ & - & - & - & - & \\
\hline \multirow{7}{*}{ CDKN3 } & \multirow{7}{*}{$\begin{array}{l}\text { cyclin-dependent } \\
\text { kinase inhibitor } 3\end{array}$} & \multirow{7}{*}{ chr14q22 } & 11730821_x_at & 1.38 & $3.26 \mathrm{E}-03$ & 2.18 & $1.32 \mathrm{E}-06$ & 1.73 & $3.77 \mathrm{E}-04$ & 2.03 & $2.64 \mathrm{E}-04$ & \multirow{7}{*}{ Cell Cycle } \\
\hline & & & 11745464 x_at & 1.45 & $5.20 \mathrm{E}-04$ & 2.22 & $1.19 \mathrm{E}-07$ & 1.66 & $8.74 E-04$ & 2.00 & $1.16 \mathrm{E}-03$ & \\
\hline & & & 11753763_x_at & 1.40 & $1.38 E-03$ & 2.22 & $1.33 \mathrm{E}-07$ & 1.68 & $3.06 \mathrm{E}-04$ & 1.96 & $2.64 \mathrm{E}-04$ & \\
\hline & & & 11753788 x_at & 1.42 & $3.34 E-03$ & 2.22 & $1.89 \mathrm{E}-07$ & 1.64 & $4.79 \mathrm{E}-04$ & 1.93 & $3.92 \mathrm{E}-04$ & \\
\hline & & & 11753831_x at at & 1.38 & $2.03 \mathrm{E}-03$ & 2.20 & $5.68 \mathrm{E}-08$ & 1.56 & $5.66 \mathrm{E}-04$ & 1.92 & $3.08 E-04$ & \\
\hline & & & 11753880 x_at & 1.57 & $6.04 E-03$ & 2.27 & $1.60 \mathrm{E}-07$ & 1.63 & $4.69 \mathrm{E}-03$ & 1.88 & $2.64 \mathrm{E}-04$ & \\
\hline & & & $11756069 \mathrm{x}$ at & 1.40 & $3.64 \mathrm{E}-03$ & 2.19 & $1.35 \mathrm{E}-07$ & 1.60 & $1.15 \mathrm{E}-03$ & 1.85 & $4.71 \mathrm{E}-04$ & \\
\hline COL11A1 & $\begin{array}{c}\text { collagen, type XI, } \\
\text { alpha 1 }\end{array}$ & chr1p21 & 11733706 _s_at & 1.31 & $7.27 \mathrm{E}-03$ & 1.31 & $2.98 \mathrm{E}-03$ & - & - & - & - & Cell Cycle \\
\hline RAD51 & RAD51 homolog & chr15q15.1 & 11734841_a_at & 2.56 & $2.17 \mathrm{E}-04$ & 1.74 & $5.94 \mathrm{E}-04$ & 1.92 & $2.30 \mathrm{E}-03$ & 1.79 & $4.66 \mathrm{E}-03$ & $\begin{array}{c}\text { Cell Cycle / DNA } \\
\text { replication }\end{array}$ \\
\hline \multicolumn{13}{|l|}{ Keys: } \\
\hline \multicolumn{13}{|c|}{ = Up-regulated } \\
\hline & \multicolumn{12}{|c|}{ = Down-regulated } \\
\hline
\end{tabular}

Figure 2. The changes in gene expression of key genes associated with Ganodermaethanol based extracts. Genes associated with cell cycle and proliferation based on the results from the Affymetrix gene expression analysis. Probes with an adjusted p-value of $>0.05$ are excluded. Up-regulated probes are highlighted in red and down-regulated probes are highlighted in green.

For cells treated with Ganoderma ethanol and spore oil extract, the expression of $B R C A 1, R A D 51$, and $C D K N 3$ are up-regulated. For BRCA1 and CDKN3, Ganoderma ethanol extract induced a greater increase in gene expression than spore oil in both PC3 and 
DU145 cell line. For RAD51, spore oil induced a greater increase in gene expression than Ganoderma ethanol.

The expression of $C D H 11$ was up-regulated in the PC3 cell line, but the changes were not significant in DU145. The expression levels of COL11A1 were significantly downregulated only in the PC3 cell line, but not in the DU145 cell line.

Figure 3 shows the top 50 genes with the greatest changes in gene expression levels after administration of Ganoderma ethanol-based extract. Five pathways are shown. Most genes are associated with cell cycle control, as DNA replication and Mitosis are part of the cell cycle process. Fourteen genes are associated with regulation of apoptosis and three overlap with cell cycle associated pathways. Five genes are associated with homophilic cell adhesion and one overlaps with cell cycle.

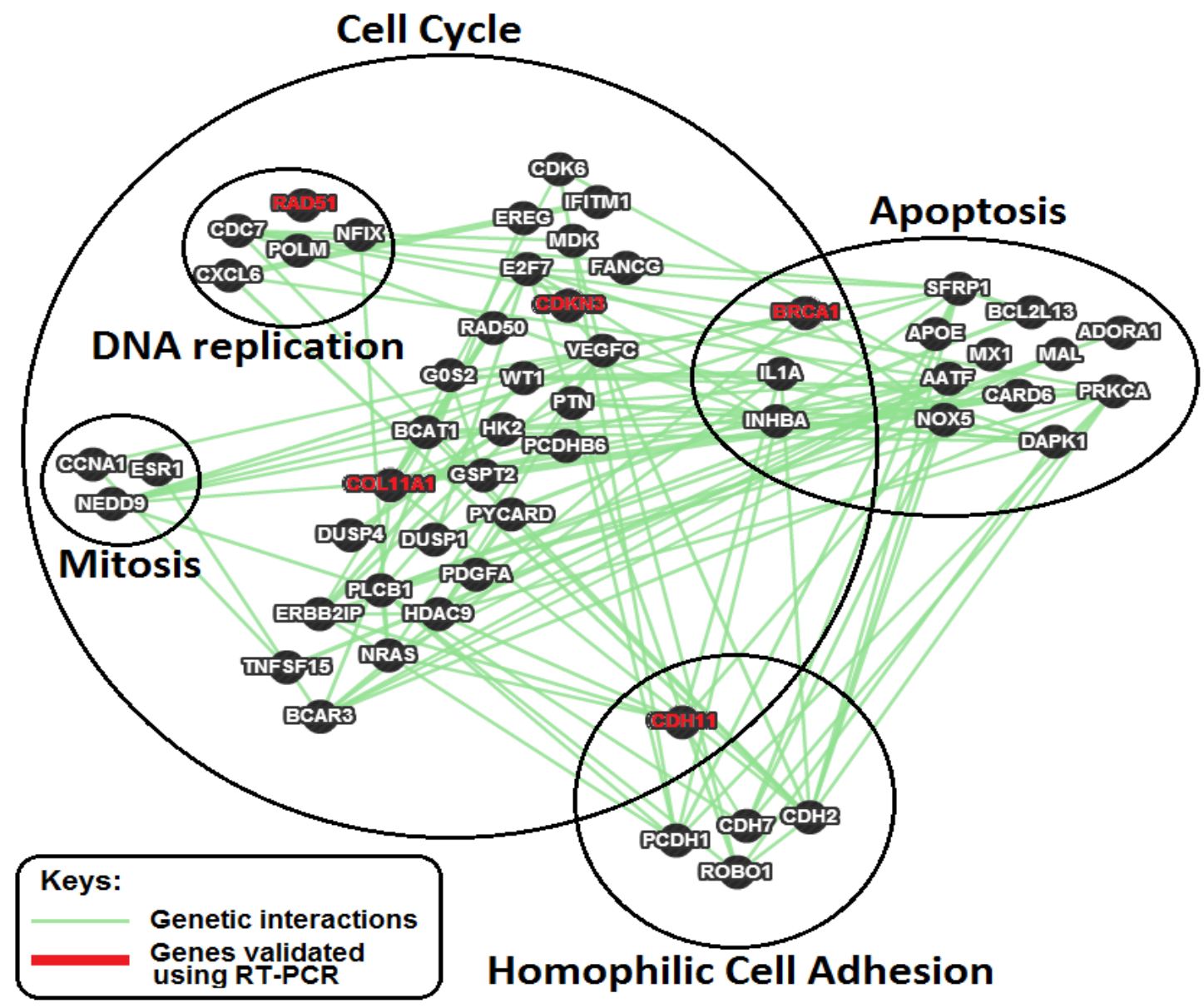

Figure 3. Genetic interactions of the top 50 genes associated with Ganoderma ethanolbased extracts. Using the result from Affymetrix analysis, the top 50 genes with the greatest changes in gene expression associated with Ganoderma ethanol-based extracts in PCa cell lines were selected. These genes were selected from a pool of genes with fold change of three or greater and a p-value of less than 0.01 . The 50 genes were inputted into GeneMANIA to identify the genetic interactions. The genes were further grouped based on their associated pathway(s).

Figure 4 shows a list of genes associated with significant changes in their expression levels following administration with Ganoderma water extract and Ganopoly. Fold change was calculated by the comparison between the extracts and media control adjusted for their respective solvents (DMSO for Ganopoly). Only probes with statistically significant adjusted $\mathrm{p}$-values $(\mathrm{p}<0.05)$ are shown, with empty blocks representing samples with nonsignificant changes in gene expression. 
The expression of S100A9 is down-regulated in both cell lines. The expression of IL1 $\alpha$ is down-regulated in PC3 and DU145 treated with Ganopoly and Ganoderma water extract. The expression of IL24 and IRFI is up-regulated after treatment with Ganopoly in both cell lines. The expression of IL24 and IRFI is also up-regulated in the PC3 cell line treated with Ganoderma water extract. IFITM1 expression is down-regulated in DU145 treated with Ganopoly and Ganoderma water extract and up-regulated in PC3 treated with the same extracts.

\begin{tabular}{|c|c|c|c|c|c|c|c|c|c|c|c|c|}
\hline \multirow{3}{*}{ Gene Symbol } & \multirow{3}{*}{ GeneTitle } & \multirow{3}{*}{$\begin{array}{c}\text { Chromosome } \\
\text { Location }\end{array}$} & \multirow{3}{*}{ ProbeSetID } & \multicolumn{4}{|c|}{$\mathrm{PC} 3$} & \multicolumn{4}{|c|}{ DU145 } & \multirow{3}{*}{ Gene Ontolog } \\
\hline & & & & \multicolumn{2}{|c|}{ Ganopoly } & \multicolumn{2}{|c|}{ Ganoderma water extract } & \multicolumn{2}{|c|}{ Ganopoly } & \multicolumn{2}{|c|}{ Ganoderma water extract } & \\
\hline & & & & Fold Change & Adj. p-value & Fold Change & Adj. p-value & Fold Change & Adj. p-value & Fold Change & Adj. p-value & \\
\hline \multirow{2}{*}{ IFITM1 } & \multirow{2}{*}{$\begin{array}{c}\text { interferon induced } \\
\text { transmembrane }\end{array}$} & \multirow{2}{*}{ chr11p15.5 } & 11715670 a at & 4.89 & $4.60 \mathrm{E}-07$ & 3.21 & $1,30 \mathrm{E}-04$ & 3.93 & $2.74 E-06$ & 2.13 & $3.28 \mathrm{E}-03$ & \multirow{2}{*}{$\begin{array}{c}\text { Immune / } \\
\text { Inflammation }\end{array}$} \\
\hline & & & 11715671_x_at & 3.87 & $6.65 \mathrm{E}-07$ & 3.24 & $1.27 \mathrm{E}-04$ & 3.42 & $2.66 \mathrm{E}-06$ & 2.40 & $3.43 \mathrm{E}-03$ & \\
\hline IL1A & interleukin 1, alpha & chr2q14 & 11725198_at & 2.00 & $4.35 E-04$ & 2.34 & $1.97 E-03$ & - & - & - & - & $\begin{array}{c}\text { Immune/ } \\
\text { Inflammation }\end{array}$ \\
\hline \multirow{3}{*}{ |L24 } & \multirow{3}{*}{ interleukin 24} & \multirow{3}{*}{ chr1q32 } & 11731834_a_at & . & . & - & - & 41.06 & $3.22 E-08$ & - & - & \multirow{3}{*}{$\begin{array}{c}\text { Immune / } \\
\text { Inflammation }\end{array}$} \\
\hline & & & 11741775_a_at & 1.23 & $2.80 \mathrm{E}-03$ & - & - & 2.02 & $2.44 E-03$ & - & - & \\
\hline & & & 11754176 a at & . & - & 1.37 & 0.04 & 46.95 & $2.49 \mathrm{E}-09$ & - & . & \\
\hline \multirow{2}{*}{ IRF1 } & \multirow{2}{*}{\begin{tabular}{c|} 
interferon \\
regulatory factor 1
\end{tabular}} & \multirow{2}{*}{ chr5q31.1 } & 11716733 at & 1.36 & $6.20 \mathrm{E}-03$ & 1.39 & 0.04 & 2.06 & $1.71 E-04$ & . & . & \multirow{2}{*}{$\begin{array}{c}\text { Immune / } \\
\text { Inflammation }\end{array}$} \\
\hline & & & 11716734 at & 1.74 & $1,39 \mathrm{E}-03$ & - & - & 1.62 & $2.09 \mathrm{E}-03$ & - & - & \\
\hline S100A9 & \begin{tabular}{|c|} 
S100 calcium \\
binding protein A9
\end{tabular} & chr1q21 & 11716523_at & 1.13 & 4.39E-06 & 2.54 & $1.38 E-04$ & 5.25 & $1.23 \mathrm{E}-06$ & 1.448942155 & 0.024635 & $\begin{array}{c}\text { Immune/ } \\
\text { Inflammation }\end{array}$ \\
\hline
\end{tabular}

Keys:

$\begin{aligned} \square & =\text { Up-regulated } \\ \square & =\text { Down-regulated }\end{aligned}$

Figure 4. The changes in gene expression of key genes associated with Ganodermawater based extracts. Genes associated with immune response and inflammation based on the result of Affymetrix gene expression analysis. Probes with an adjusted p-value of $>0.05$ are excluded. Up-regulated probes are highlighted in red and down-regulated probes are highlighted in green.

Figure 5 shows the top 50 genes with the greatest changes in gene expression levels after administration of Ganoderma water-based extract. Four pathways are shown. Over half of the top genes are associated with immune/inflammation pathways. There are 20 genes associated with cell proliferation, 12 genes are associated with apoptosis, and four genes are associated with angiogenesis. Each pathway contains gene(s) that overlap with other pathways. In addition, IL8 is involved in all four pathways.

RT-PCR: Two biological repeats and three technical repeats were performed per sample-treatment combination.

Cycle threshold of GAPDH and selected genes in RT-PCR: The Ct in the amplification plot was checked to ensure that it intersected the linear portion of the amplification curve. The plateau suggested the depletion of the TaqMan® probe, which prevented further increase in fluorescent intensity. Therefore, at the plateau, the fluorescent intensity no longer reflects the level of PCR product. The absorbance value at the $\mathrm{Ct}$ was generated. An amplification plot of GAPDH (Figure 6a) showed the Ct ranges between 16 and 26. In the amplification plot with all gene primers (Figure 6b), the smallest $\mathrm{Ct}$ is 21 and highest $\mathrm{Ct}$ is 25.3 which both lie between 16 and 26 . 


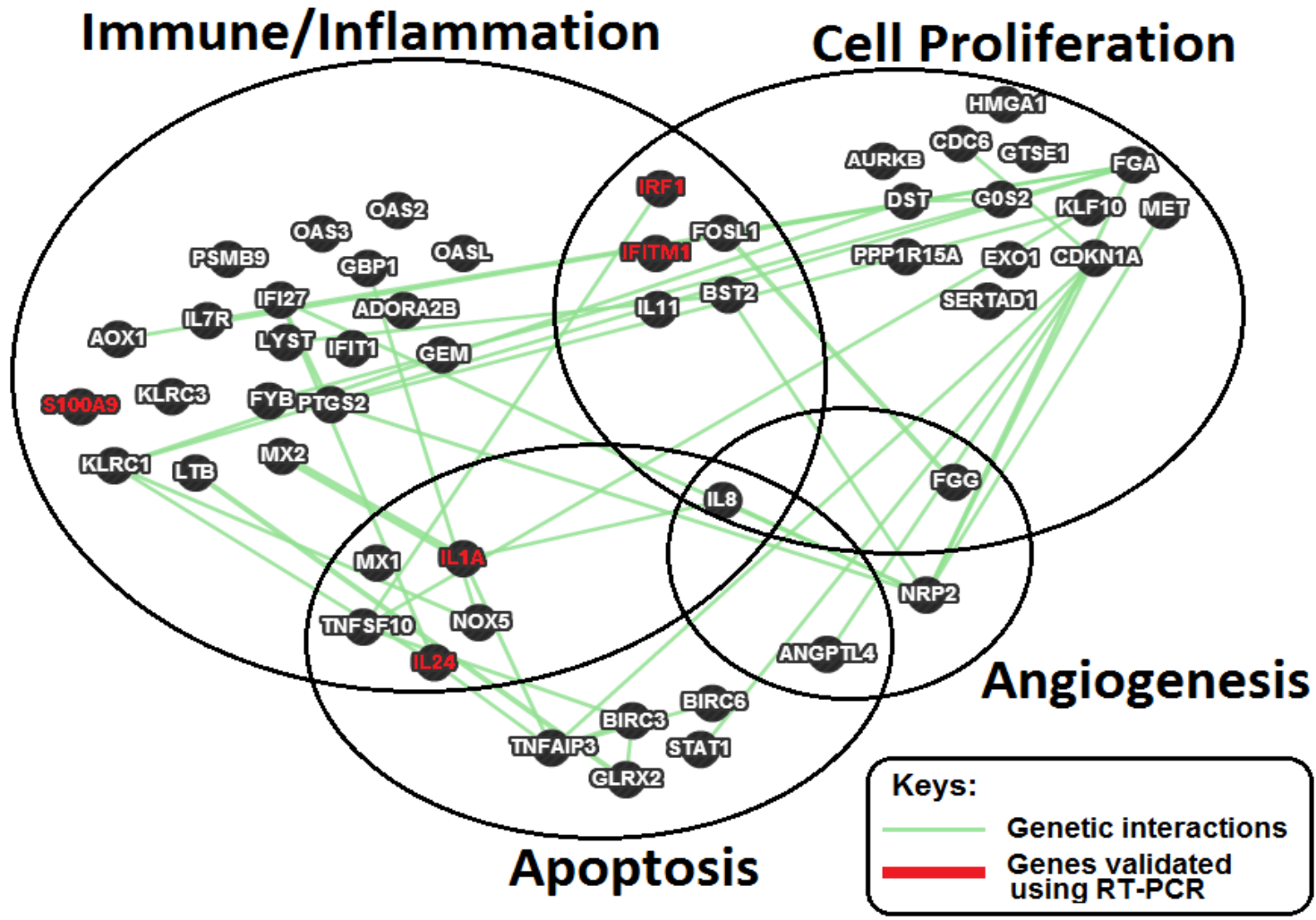

Figure 5. Genetic interactions of the top 50 genes associated with Ganoderma waterbased extracts. Using the result from Affymetrix analysis, the top 50 genes with the greatest changes in gene expression associated with Ganoderma water-based extracts in PCa cell lines were selected. These genes were selected from a pool of genes with fold change of three or greater and a p-value of less than 0.01 . The 50 genes were inputted into GeneMANIA to identify the genetic interactions. The genes were further grouped based on their associated pathway(s).
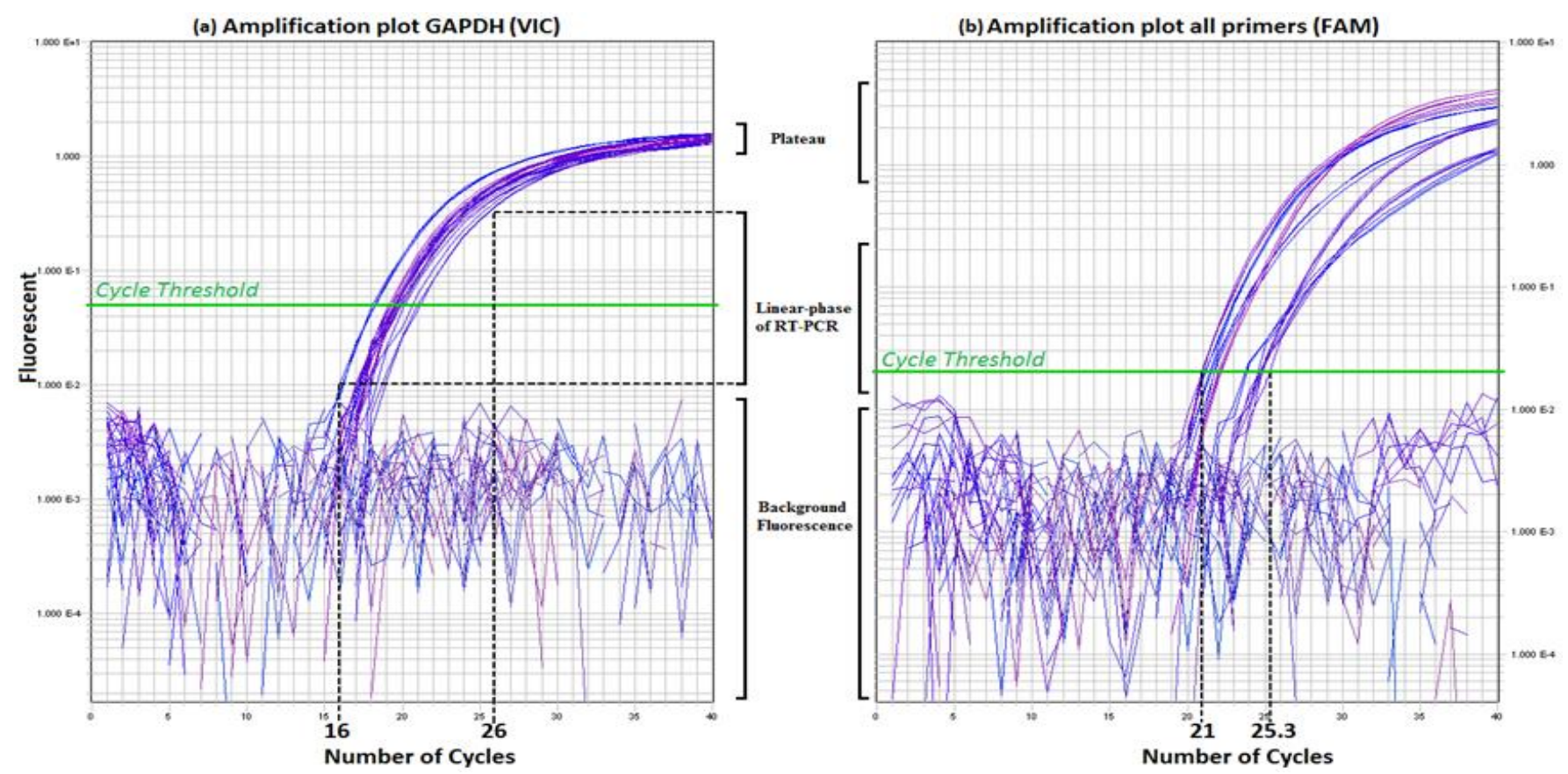

Figure 6. RT-PCR amplification plots from the PC3 cell line treated with media. (a) Amplification plot of fluorescent profile of GAPDH housekeeping gene with the VIC® detector. (b) Amplification plot of the fluorescent profiles of the 11 selected genes with FAM ${ }^{\mathrm{TM}}$ detector. 
RT-PCR comparison with Affymetrix gene expression results: A comparison of the fold changes in gene expression between RT-PCR and Affymetrix analysis is shown in Figures 7 and 8 . The changes in gene expression were normalized with media control and expressed as fold change. Positive values for fold change represent up-regulation of gene expression while negative values represent down-regulation. Overall, RT-PCR and Affymetrix showed similar gene expression trends. Expression levels of IRFI and IL24 are higher in RT-PCR analysis than Affymetrix in Ganoderma water and Ganopoly respectively (Figure 7). The gene expression levels of $C D K N 3, R A D 51$, and BRCA1 are also higher in RT-PCR than the Affymetrix analysis after treatment with Ganoderma ethanol (Figure 8).

$-10$

$-5$

0

5

10

15

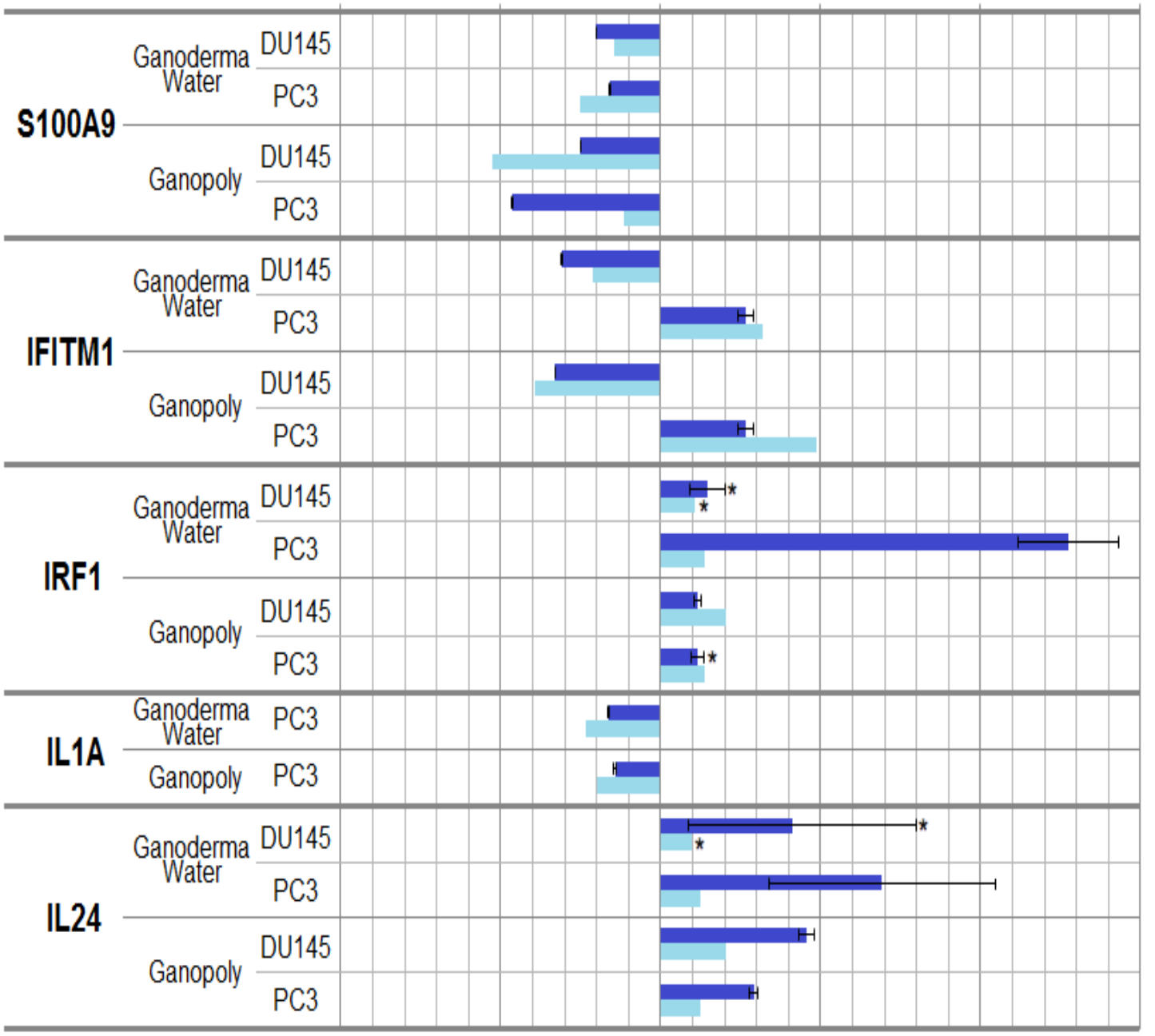

Key:
$\square$ RT-PCR
$\square$ Affymetrix $\quad \begin{array}{r}\text { * non-statistically significant } \\ \text { changes in gene expression }\end{array}$

Figure 7. Comparison of gene expression levels measured by RT-PCR and Affymetrix. Comparison of the changes in gene expression levels after treatment with Ganoderma water-based extracts between RT-PCR and Affymetrix analysis in DU145 and PC3 cell lines. The probes for $I L 1 \alpha$ had failed to amplify in DU145 cell line and are excluded from the figure. ILI $\alpha=$ interleukin 1-alpha. 


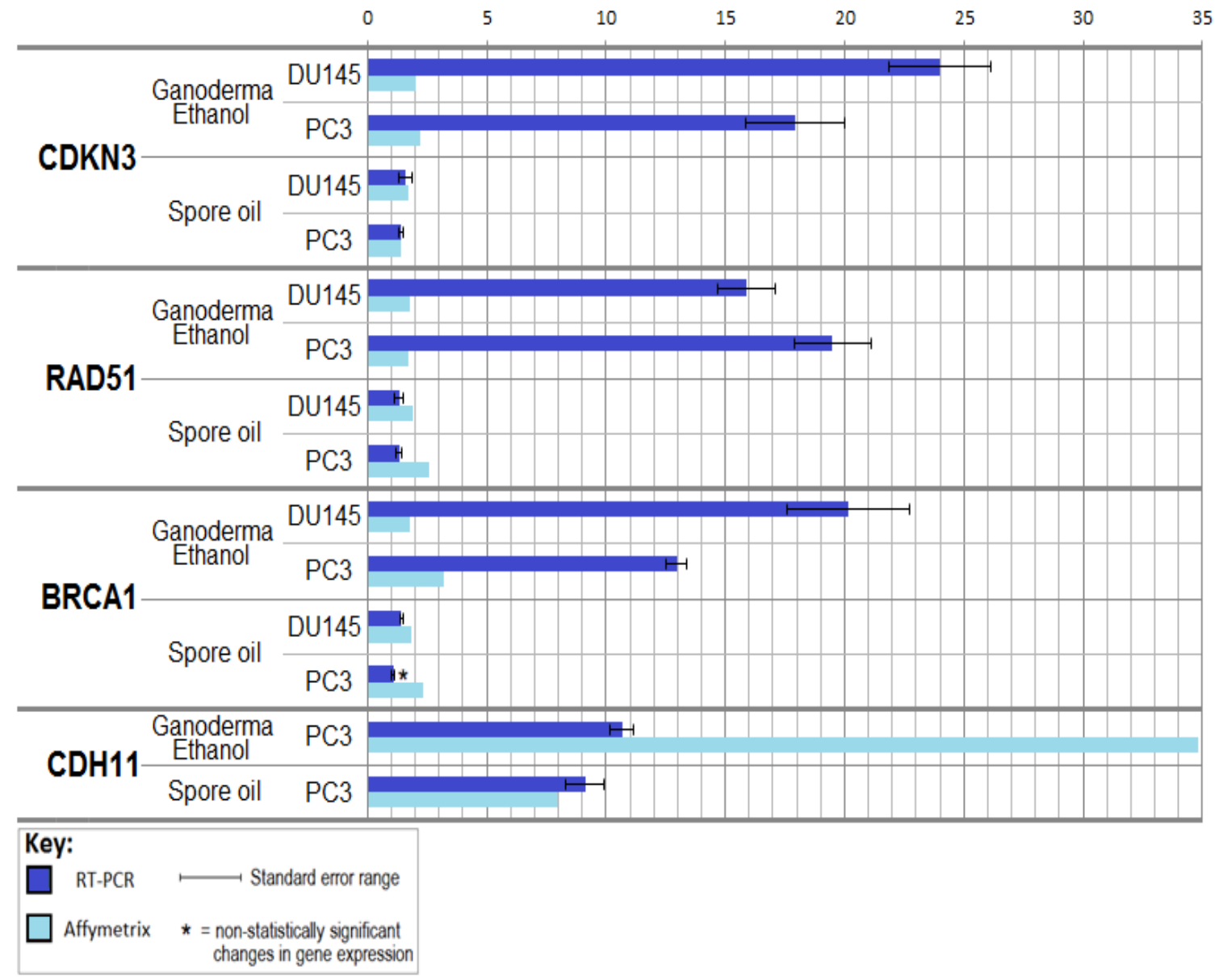

Figure 8. Comparison of gene expression levels measured by RT-PCR and Affymetrix. Comparison of the changes in gene expression levels after treatment with Ganoderma ethanol-based extracts between RT-PCR and Affymetrix analysis in DU145 and PC3 cell lines. The probes for CDH11 had failed to amplify in DU145 cell line and are excluded from the figure. CDH11 = Cadherin 11, type 2.

\section{DISCUSSION}

The development of cancerous cells is a multistep process involving normal cells acquiring several hallmarks of cancer to evolve to a neoplastic state. These biological capabilities of malignant cells can be targeted for the treatment of cancer. Treatment with Ganodermabased extracts resulted in changes in the gene expression levels of a number of genes. The use of an Affymetrix array has permitted characterization of the expression levels of large numbers of genes simultaneously. This allowed the examination and discovery of biologically active pathways associated with the anti-cancer activity of G. lucidum.

Cell cycle control and proliferation: Treatment of PC3 and DU145 cancer cells with Ganoderma extracts containing triterpenes (Ganoderma ethanol extract and spore oil extract) resulted in changes in gene expression associated with cell proliferation and regulation of cell cycle. One of the hallmarks of cancer is the deregulation of cellular proliferation [35]. The cell cycle is a process cells undergo in order to divide and proliferate, and various successful anti-cancer drugs act by inhibiting the cell cycle [36]. In addition, expression of genes associated with mitosis was also affected. Mitosis is a critical and highly regulated step in the cell cycle. Mitosis regulates the division and passage of genetic information from 
one cell generation to the next. Errors in mitosis can lead to uncontrolled proliferation and culmination of genetic instability, which can further promote cancer development [37]. Since cancer cells are rapidly dividing cells which constantly undergo mitosis, anti-cancer drugs targeting mitosis have the potential to be highly selective and sensitive. Current antimitotic drugs cannot completely eradicate cancer cells, and are often associated with not only a high level of toxicity, but also with the development of drug resistance in cancer cells [38].

Affymetrix array analysis and pathway analysis have been used to identify a list of genes associated with cell cycle control that are regulated by ethanol-based Ganoderma extracts. We have identified over 200 unique genes associated with cell cycle control that showed significant changes in their expression levels after treatment with ethanol-based Ganoderma extracts (Table 3). It is not feasible to examine and compare the expression levels of every single gene identified as being significantly differentially expressed in the Affymetrix array and pathway analysis. Instead, high-penetrance genes with strong association with cancer based on literature findings were selected to undergo further analysis. In particular, two genes, namely BRCA1 and $C D K N 3$, which are known tumour suppressor genes (TSGs), were up-regulated by ethanol-based Ganoderma extracts.

Genes associated with Cell cycle control: $B R C A 1$ is a TSG involved in the repair of DNA damage and in the control of the cell cycle from $\mathrm{G}_{2}$ to $M$ phase [39]. Various studies have identified $B R C A 1$ as a major TSG in breast cancer and other cancer types, including cancer of the prostate [40, 41, 42]. The expression of BRCA1 in PC3 and DU145 was up-regulated after treatment with spore oil and Ganoderma ethanol extract. BRCAI directly interacts and enhances the activity of androgen receptors (AR) and induces the expression of CDKNs, leading to increased androgen-induced cell death in PCa cells [43, 44]. Therefore, overexpression of $B R C A 1$ together with androgen stimulation via AR can inhibit cell cycle progression and increase apoptosis in PCa. Both PC3 and DU145 are aggressive androgenindependent cell lines [45]. This suggests that BRCA1 inhibition of cell cycle progression via AR should not affect PC3 and DU145 cell lines. However, Alimirah et al. [46] have shown that both PC3 and DU145 still express low levels of AR. Therefore, up-regulation of BRCA1 followed by AR-dependent inhibition of cell cycle progression may be one of the biologically active pathways through which Ganoderma ethanol-based extracts exert their growth inhibitory effect in PC3 and DU145.

Progression of the cell cycle is closely regulated by a series of cyclin-dependent kinase (CDK) and their inhibitors [47]. CDKN3 dephosphorylates and inhibits CDK2 which is essential for the $G_{1} / S$ transition of the cell cycle [48].

As shown in Figure 2 the expression profiles of $C D K N 3$ and BRCAl are similar. Ganoderma ethanol extract induced a greater increase in gene expression than spore oil in DU145 and PC3 cell lines. Conclusions drawn from other studies which showed BRCA1 upregulated expression levels of CDK inhibitors suggest that CDKN3 may be one of the down-stream targets up-regulated by BRCA1 [49, 50].

A gene associated with DNA repair: $R A D 51$ is involved in the repair of DNA double strand breakages [51]. Overexpression of RAD51 results in a variety of consequences including increased resistance to DNA damaging agents, disruption of the cell cycle, and apoptotic cell death [51]. Overexpression of $R A D 51$ is also associated with more aggressive 
forms of PCa [52]. Up-regulation of RAD51 may be beneficial for inhibiting earlier stages of $\mathrm{PCa}$ but can enhance progression of more aggressive forms of PCa. Alternately, it is also possible that the observed up-regulation of RAD51 is simply an indication of genomic instability caused by inhibition of cell cycle as a result of Ganoderma administration [53].

Genes associated with Wnt/ק-catenin signalling pathway: Both $C D H 11$ and $C O L 11 A 1$ are associated with the $\mathrm{Wnt} / \beta$-catenin signalling pathway $[54,55,56]$. We have found that treatment of PC3 cells with Ganoderma ethanol-based extracts caused a significant increase in the expression of CDH11. CDH11 is involved in cell-cell adhesion, and increased expression in tumours is associated with a reduced risk of metastasis [54]. Down-regulation of $C D H 11$ expression via hyper-methylation of $C D H 11$ genes is commonly observed in metastatic cancers [57]. Thus, increased CDH11 expression could promote cell-cell adhesion of PC3 and reduce the risk of metastasis via cell detachments.

Likewise, our results have indicated that treatment of PC3 cells with Ganoderma ethanol-based extracts caused a significantly reduced expression of COL11A1. COL11A1 is a type of protein which forms collagen [58]. Collagen is a major substituent of the extracellular matrix (ECM), and its degradation in tissue is associated with tumour aggressiveness and risk of metastasis [59]. Collagen levels in PCa tissues were found to be significantly associated with Gleason score, a system used to determine PCa stage and aggressiveness [58]. Studies have reported that increased COL11A1 expression is associated with more aggressive cancers, including PCa [58, 60].

CDH11, in addition to cell-cell adhesion, may also be involved in cell cycle and apoptosis via the $\mathrm{Wnt} / \beta$-catenin signalling pathway [55]. The $\mathrm{Wnt} / \beta$-catenin signalling pathway is often up-regulated in advanced cancer. The overexpression of this pathway has been reported as being related to drug-resistance in cancer, as well as epithelialmesenchymal transition, which promotes metastasis [61, 62]. Studies [54, 55] have reported that $C D H 11$ acts as a tumour-suppressor and inhibits the $\mathrm{Wnt} / \beta$-catenin signalling pathway. In addition, Fischer et al. [56] have reported that in colorectal cancer, with overactive $\mathrm{Wnt} / \beta$-catenin signalling, COL11A1 is found to be overexpressed. This suggests that COL11A1 expression is associated with $\mathrm{Wnt} / \beta$-catenin signalling. Furthermore, Jedinak et al. [63] have shown that an extract of G. lucidum can inhibit growth of colorectal cancer cell lines via reducing $\beta$-catenin expression. Wnt/ $\beta$-catenin signalling is involved in the activation of $\beta$-catenin, which is degraded and inhibited by the Fas ligand [64]. PC3 is Fassensitive and DU145 is Fas-resistant [65]. Therefore, the down-regulation of COL11A1 and up-regulation of $C D H 11$, which is only observed in the Fas-sensitive PC3, may be associated with the Fas-signalling pathway. The down-regulation of COL11A1 and upregulation of $\mathrm{CDH} 11$ are indicators of decreased cell proliferation and increased apoptosis via Wnt/ $\beta$-catenin and Fas-signalling pathways.

Immune response and inflammation: Treatment of PC3 and DU145 cancer cells with Ganoderma extracts containing polysaccharides (Ganoderma water extract and Ganopoly) resulted in changes in gene expression associated with immune response activity. Several studies have shown that Ganoderma polysaccharides can exert their anti-cancer activity via stimulating the host's immune system [16, 66, 67]. However, as there are no immune cells present in cell culture, changes in immune activity does not explain the observed growth inhibition in $\mathrm{IC}_{50}$ cell line studies. 
Inflammatory response is closely associated with immune response and plays a role in the development and survival of cancer cells [68, 69]. Inflammation has been linked as a causal agent in around $20 \%$ of cancer cases [70,71]. Men diagnosed with chronic prostatitis (inflammation of the prostate) have an increased risk of developing PCa, while men taking non-steroidal anti-inflammatory drugs (NSAIDs) for a prolonged period have a decreased risk of PCa [70, 71]. Therefore, it is possible that Ganoderma polysaccharides can directly affect the survival and proliferation of PCa cells via regulation of inflammation. In addition, chronic inflammation is also associated with a host of diseases other than cancer. $G$. lucidum's ability to regulate inflammation may contribute to its wide range of health benefits.

In this study, Affymetrix array analysis and pathway analysis have been used to identify a list of genes affected by treatment with Ganoderma water extract and Ganopoly. Several genes which are significantly associated with inflammation were affected by treatment with the two extracts, which warrant further analysis.

IL1 $\alpha$ was down-regulated in PC3 cell lines treated with water-based Ganoderma extracts. IL1 $\alpha$ promotes immune responses by inducing IL2 production and stimulates proliferation of other immune cells. ILI $\alpha$ also promotes a pro-inflammatory response by stimulating the release of prostaglandin and collagenase, andpromotes cell survival and angiogenesis by stimulating production of growth factors: Vascular endothelial growth factor (VEGF), Interleukin 8 (IL8), Interleukin 6 (IL6), Tumour necrosis factor- $\alpha$ (TNF- $\alpha)$, and Tumour growth factor- $\beta(T G F-\beta)$ in the tumour microenvironment, and further promotes metastatic activity by stimulating production of matrix metalloproteinase enzymes. $I L 1 \alpha$ is up-regulated in breast, colon, lung, head and neck cancers, and melanomas, and it is associated with more aggressive cancer and poorer survival [72]. Therefore, downregulation of ILI $\alpha$ should reduce cancer aggressiveness. In this study, IFITMI was found to be down-regulated in the DU145 cell line and up-regulated in the PC3 cell line. IFITM1 is crucial for the anti-proliferative action of IFN- $\gamma$ either by inhibiting ERK activation or by arresting cell growth in the $G_{1}$ phase in a p53-dependent manner [73]. PC3 cells are sensitive to the anti-proliferative effect of IFN- $\gamma$, while DU145 is resistant [74]. The downregulation in gene expression levels of IFITM1 in DU145 may explain why DU145 is resistant to the anti-proliferative effects of IFN- $\gamma$.

We have found the expression of IL24 to be strongly up-regulated by Ganopoly in DU145. Some probes of IL24 were also found to be increased in PC3 treated with Ganoderma water-based extracts. IRF1 has similar expression profiles to IL24. Both IL24 and IRFI are TSGs and exert anti-cancer activities via activation of STAT1 and STAT3 transcription factors $[75,76,77,78]$. Up-regulation of $I L 24$ and IRFI has anti-proliferative effects in breast and colon cancers $[75,76,77,78]$. Due to the variation between the probe expression levels of the above mentioned two genes in Ganopoly treated DU145 (between a 2 to 40-fold increase), we cannot determine the exact level of up-regulation exerted by Ganopoly. In addition, for PC3 treated with Ganoderma water extract, only one out of three probes showed significant up-regulation, while the other two probes showed nonstatistically significant changes. Affymetrix array analysis showed evidence that treatment of Ganoderma water extract increased expression of IL24 which promotes growth inhibition of cancers.

We have found the expression of $S 100 A 9$ to be down-regulated after treatment with Ganoderma water-based extracts. S100A9 is overexpressed in many cancer types including 
PCa [79]. However, S100A9 is not expressed in healthy prostate tissues [80]. Its expression is induced by hypoxia, which is common in tumours [81]. The up-regulated S100A9 expression promotes inflammation via up-regulation of IL8 [82]. Therefore, the observed down-regulation of $S 100 A 9$ can potentially reduce inflammation and may be the cause of the down-regulation of other pro-inflammatory cytokines observed in other studies after treatment of Ganoderma extracts [83, 84, 85].

Comparison of gene expression levels between RT-PCR and Affymetrix: The gene expression levels obtained from RT-PCR analysis were compared to the gene expression levels from Affymetrix analysis. For water-based extracts (Ganoderma water extract and Ganopoly), we compared the gene expression levels of S100A9, IFITM1, IL1 $\alpha$, IL24, and IRFI between RT-PCR and Affymetrix array and found similar expression profiles (Figure 7). For ethanol-based extracts (Ganoderma ethanol extract and spore oil extract), we compared the gene expression levels of $C D K N 3, R A D 51, C D H 11$, and BRCA1 between RTPCR and Affymetrix array (Figure 8). Likewise, we found similar expression profiles. Overall, a comparison between RT-PCR and Affymetrix array analyses showed similar expression profiles. However a greater fold change was observed in TR-PCR than Affymetrix. This may be due to the inclusion of only one housekeeping gene for reference in the RT-PCR analysis. Therefore, we can conclude that the results from RT-PCR support the result from Affymetrix array analyses, at least in terms of whether a gene is up- or down-regulated.

\section{CONCLUSIONS}

Utilizing IC50 tissue culture, we have found that the ethanol-based Ganoderma extracts have stronger growth inhibitory effects than extracts obtained with water-based extraction methods. In particular, the extract of Ganoderma spore oil showed the greatest growth inhibitory activity when compared to the other extracts tested. This suggests that the section of G. lucidum which contains the highest level of anti-cancer active ingredients may be its spores. However, other extracts tested in this study also showed significant growth inhibitory activities through different biologically active pathways, thus their anti-cancer potential should not be disregarded.

Utilizing Affymetrix array analysis, we have identified several biologically active pathways associated with the growth inhibitory activity of Ganoderma extracts on PCa cell lines. Several key genes that are associated with cancer suppression and progression were found to be influenced by Ganoderma extracts. These findings are supported in the literature to be significantly associated with cancer development and progression. Examination of the protein expression of these genes, using Western blot, could further validate and support our results from the Affymetrix array analysis. Additional investigations into other key genes associated with the anti-cancer activities of Ganoderma would provide a broader understanding of the anti-cancer functions of Ganoderma. Moreover, further analysis of the wealth of data generated via Affymetrix array analysis may identify novel pathways and interaction of genes associated with cancer pathology. In the modern era of "personalized medicine," the identification of anti-cancer and anti-inflammatory activities of G. lucidum can promote its use in humans, both as a supplement to improve health and as therapy for the treatment and prevention of cancer. 


\section{List of abbreviations used}

$\begin{array}{ll}\text { AR } & \text { Androgen receptors } \\ \text { BRCA1 } & \text { Breast Cancer type 1 } \\ \text { CDH11 } & \text { Cadherin 11, type 2 } \\ \text { CDK } 2 & \text { Cyclin-dependent kinase 2 } \\ \text { CDKN3 } & \text { Cyclin-dependent kinase inhibitor 3 } \\ \text { COL11A1 } & \text { Collagen, type XI, alpha 1 } \\ \text { DMSO } & \text { Dimethyl Sulfoxide } \\ \text { ECM } & \text { extracellular matrix } \\ \text { GAPDH } & \text { Glyceraldehyde 3-phosphate dehydrogenase } \\ \text { GATHER } & \text { Gene Annotation Tool to Help Explain Relationships } \\ \text { IFITM1 } & \text { interferon induced transmembrane protein 1 } \\ \text { IL1 } \alpha & \text { interleukin 1-alpha } \\ \text { IL24 } & \text { interleukin 24 } \\ \text { IL6 } & \text { Interleukin 6 } \\ \text { IL8 } & \text { Interleukin } 8 \\ \text { IRF1 } & \text { interferon regulatory factor 1 } \\ \text { PCa } & \text { prostate cancer } \\ \text { RT-PCR } & \text { real time - polymerase chain reaction } \\ \text { S100A9 } & \text { S100 calcium binding protein A9 } \\ \text { TGF } \beta & \text { Tumour growth factor- } \beta \\ \text { TNF } \alpha & \text { Tumour necrosis factor- } \alpha \\ \text { TSG } & \text { Tumour suppressor genes } \\ V E G F & \text { vascular endothelial growth factor }\end{array}$

Competing interests: CHJK received financial support from the supplier of the wild $G$. lucidum.

Authors' contributions: CHJK, KSB, MPG, and LRF designed the study. CHJK carried out the tissue culture study. DYH provided statistical support. PMM participated in RNA extraction and RT-PCR analysis. MPG participated in overall study design and provided wild G. lucidum. GJM participated in RNA stdsen analysis and preparation for Affymetrix gene expression analysis. CHJK and KSB drafted and made critical revisions of the manuscript and all authors commented on the manuscript. All authors read and approved the final manuscript.

Acknowledgements and Funding: The authors acknowledge the University of Auckland for providing access to the resources necessary for the completion of this manuscript. We would also like to thanks Shuotun Zhu (Auckland Cancer Society Research Centre, Faculty of Medicine \& Health Science) for providing his expertise in extraction of G. lucidum.

\section{REFERENCES:}

1. Paterson RR: Ganoderma - a therapeutic fungal biofactory. Phytochemistry. 2006, 67(18):1985-2001.

2. Wachtel-Galor S, Yuen J, Buswell JA, Benzie IFF. Ganoderma lucidum (Lingzhi or Reishi): A Medicinal Mushroom. In: Benzie IFF, Wachtel-Galor S, editors. Herbal 
Medicine: Biomolecular and Clinical Aspects. 2nd ed. Boca Raton: CRC Press; 2011. p. 53-76.

3. Kao CHJ, Jesuthasan AC, Bishop KS, Glucina MP, Ferguson LP: Anti-cancer Activities of Ganoderma lucidum: Active Ingredients and Pathways. Functional Foods in Health and Disease. 2013, 3(2):48-65.

4. Sanodiya BS, Thakur GS, Baghel RK, Prasad GB, Bisen PS: Ganoderma lucidum: a potent pharmacological macrofungus. Curr Pharm Biotechnol. 2009, 10(8):717-742.

5. Jong SC, Birmingham JM: Medicinal benefits of the mushroom Ganoderma. Adv Appl Microbiol. 1992, 37:101-134.

6. Lindequist U, Niedermeyer TH, Julich WD: The pharmacological potential of mushrooms. Evid Based Complement Alternat Med. 2005, 2(3):285-299.

7. Wang G, Zhao J, Liu J, Huang Y, Zhong JJ, Tang W: Enhancement of IL-2 and IFN-gamma expression and NK cells activity involved in the anti-tumor effect of ganoderic acid Me in vivo. Int Immunopharmacol. 2007, 7(6):864-870.

8. Gao Y, Gao H, Chan E, Tang W, Xu A, Yang H, Huang M, Lan J, Li X, Duan W, $\mathrm{Xu} \mathrm{C}$, Zhou S: Antitumor activity and underlying mechanisms of ganopoly, the refined polysaccharides extracted from Ganoderma lucidum, in mice. Immunol Invest. 2005, 34(2):171-198.

9. Gao Y, Zhou S, Jiang W, Huang M, Dai X: Effects of ganopoly (a Ganoderma lucidum polysaccharide extract) on the immune functions in advanced-stage cancer patients. Immunol Invest. 2003, 32(3):201-215.

10. Bach JP, Deuster O, Balzer-Geldsetzer M, Meyer B, Dodel R, Bacher M: The Role of Macrophage Inhibitory Factor in Tumorigenesis and Central Nervous System Tumors. Cancer. 2009, 115(10):2031-2040.

11. Mantovani A, Sica A: Macrophages, innate immunity and cancer: balance, tolerance, and diversity. Curr Opin Immunol. 2010, 22(2):231-237.

12. Chang ST. Mushrooms cultivation, nutritional value, medicinal effect, and environmental impact. Miles PG, Chang ST, editors. Boca Raton, Fla.: Boca Raton, Fla: CRC Press; 2004.

13. Kijima M, Saio M, Oyang GF, Suwa T, Miyauchi R, Kojima Y, Imai H, Nakagawa J, Nonaka K, Umemura N, Nishimura T, Takami T: Natural killer cells play a role in MHC class I in vivo induction in tumor cells that are MHC negative in vitro. Int $\mathbf{J}$ Oncol. 2005, 26(3):679-684.

14. Pillai TG, Savi VP, Maurya DK, Nair CKK, Janardhanan KK: Prevention of radiation-induced damages by aqueous extract of Ganoderma lucidum occurring in southern parts of India. Curr Sci India. 2006, 91(3):341-344.

15. Smina TP, De S, Devasagayam TP, Adhikari S, Janardhanan KK: Ganoderma lucidum total triterpenes prevent radiation-induced DNA damage and apoptosis in splenic lymphocytes in vitro. Mutat Res. 2011, 726(2):188-194.

16. Chen WC, Hau DM, Lee SS: Effects of Ganoderma lucidum and krestin on cellular immunocompetence in gamma-ray-irradiated mice. Am J Chin Med. 1995, 23(1):7180.

17. Sheena N, Ajith TA, Janardhanan KK: Prevention of nephrotoxicity induced by the anticancer drug cisplatin, using Ganoderma lucidum, a medicinal mushroom occurring in South India. Curr Sci India. 2003, 85(4):478-482. 
18. Furusawa E, Chou SC, Furusawa S, Hirazumi A, Dang Y: Antitumour activity of Ganoderma lucidum, an edible mushroom, on intraperitoneally implanted lewis lung carcinoma in synergenic mice. Phytotherapy Research. 1992, 6(6):300-304.

19. Jin X, Ruiz Beguerie J, Sze DM, Chan GC: Ganoderma lucidum (Reishi mushroom) for cancer treatment. Cochrane Database Syst Rev. 2012, 6:CD007731.

20. Lu H, Kyo E, Uesaka T, Katoh O, Watanabe H: A water-soluble extract from cultured medium of Ganoderma lucidum (Rei-shi) mycelia suppresses azoxymethane-induction of colon cancers in male F344 rats. Oncol Rep. 2003, 10(2):375-379.

21. Gao Y, Zhang R, Zhang J, Gao S, Gao W, Zhang H, Wang H, Han B: Study of the extraction process and in vivo inhibitory effect of ganoderma triterpenes in oral mucosa cancer. Molecules. 2011, 16(7):5315-5332.

22. Sheng S: The urokinase-type plasminogen activator system in prostate cancer metastasis. Cancer Metastasis Rev. 2001, 20(3-4):287-296.

23. Lakshmi B, Ajith TA, Sheena N, Gunapalan N, Janardhanan KK: Antiperoxidative, anti-inflammatory, and antimutagenic activities of ethanol extract of the mycelium of Ganoderma lucidum occurring in South India. Teratog Carcinog Mutagen. 2003, Suppl 1:85-97.

24. Cara CJ, Pena AS, Sans M, Rodrigo L, Guerrero-Esteo M, Hinojosa J, GarciaParedes J, Guijarro LG: Reviewing the mechanism of action of thiopurine drugs: towards a new paradigm in clinical practice. Med Sci Monit. 2004, 10(11):RA247254.

25. Hawwa AF, Millership JS, Collier PS, Vandenbroeck K, Mccarthy A, Dempsey S, Cairns C, Collins J, Rodgers C, Mcelnay JC: Pharmacogenomic studies of the anticancer and immunosuppressive thiopurines mercaptopurine and azathioprine. $\mathrm{Br}$ J Clin Pharmacol. 2008, 66(4):517-528.

26. Skehan P, Storeng R, Scudiero D, Monks A, Mcmahon J, Vistica D, Warren JT, Bokesch H, Kenney S, Boyd MR: New colorimetric cytotoxicity assay for anticancer-drug screening. J Natl Cancer Inst. 1990, 82(13):1107-1112.

27. Vermeulen J, De Preter K, Lefever S, Nuytens J, De Vloed F, Derveaux S, Hellemans J, Speleman F, Vandesompele J: Measurable impact of RNA quality on gene expression results from quantitative PCR. Nucleic Acids Res. 2011, 39(9):e63.

28. Opitz L, Salinas-Riester G, Grade M, Jung K, Jo P, Emons G, Ghadimi BM, Beissbarth T, Gaedcke J: Impact of RNA degradation on gene expression profiling. BMC Med Genomics. 2010, 3:36.

29. Merabishvili VM: [Breast cancer: morbidity, mortality, survival (population study)]. Vopr Onkol. 2011, 57(5):609-615.

30. Lopez-Basave HN, Morales-Vasquez F, Ruiz Molina JM, Gonzalez-Enciso A, Namendys-Silva SA, Medina Castro JM, Montalvo-Esquivel G, Herrera-Gomez A, De La Garza Salazar JG: Morbidity and mortality of cytoreductive surgery with hyperthermic intraperitoneal chemotherapy: national cancer institute, Mexico city, Mexico. ISRN Oncol. 2011, 2011:526384.

31. R Development Core Team. R: A language and environment for statistical computing. Team. RDC, editor. Vienna, Austria: R Foundation for Statistical Computing; 2010. 
32. Wakefield J: Bayes factors for genome-wide association studies: comparison with Pvalues. Genet Epidemiol. 2009, 33(1):79-86.

33. Chappell J, Dalton S: Altered cell cycle regulation helps stem-like carcinoma cells resist apoptosis. BMC Biol. 2010, 8:63.

34. Smith DM, Gao G, Zhang X, Wang G, Dou QP: Regulation of tumor cell apoptotic sensitivity during the cell cycle (Review). Int J Mol Med. 2000, 6(5):503-507.

35. Hanahan D, Weinberg RA: Hallmarks of cancer: the next generation. Cell. 2011, 144(5):646-674.

36. Vermeulen K, Van Bockstaele DR, Berneman ZN: The cell cycle: a review of regulation, deregulation and therapeutic targets in cancer. Cell Prolif. 2003, 36(3):131-149.

37. Schmit TL, Ahmad N: Regulation of mitosis via mitotic kinases: new opportunities for cancer management. Mol Cancer Ther. 2007, 6(7):1920-1931.

38. Chan KS, Koh CG, Li HY: Mitosis-targeted anti-cancer therapies: where they stand. Cell Death Dis. 2012, 3:e411.

39. Cathcart MC, O'byrne KJ, Reynolds JV, O'sullivan J, Pidgeon GP: COX-derived prostanoid pathways in gastrointestinal cancer development and progression: novel targets for prevention and intervention. Biochim Biophys Acta. 2012, 1825(1):49-63.

40. Jarvis EM, Kirk JA, Clarke CL: Loss of nuclear BRCA1 expression in breast cancers is associated with a highly proliferative tumor phenotype. Cancer Genet Cytogenet. 1998, 101(2):109-115.

41. Rabiau N, Dechelotte P, Adjakly M, Kemeny JL, Guy L, Boiteux JP, Kwiatkowski F, Bignon YJ, Bernard-Gallon D: BRCA1, BRCA2, AR and IGF-I expression in prostate cancer: correlation between RT-qPCR and immunohistochemical detection. Oncol Rep. 2011, 26(3):695-702.

42. Leongamornlert D, Mahmud N, Tymrakiewicz M, Saunders E, Dadaev T, Castro E, Goh C, Govindasami K, Guy M, O'brien L, Sawyer E, Hall A, Wilkinson R, Easton D, Goldgar D, Eeles R, Kote-Jarai Z: Germline BRCA1 mutations increase prostate cancer risk. Br J Cancer. 2012, 106(10):1697-1701.

43. Yeh S, Hu YC, Rahman M, Lin HK, Hsu CL, Ting HJ, Kang HY, Chang C: Increase of androgen-induced cell death and androgen receptor transactivation by BRCA1 in prostate cancer cells. Proc Natl Acad Sci U S A. 2000, 97(21):1125611261.

44. Castro E, Eeles R: The role of BRCA1 and BRCA2 in prostate cancer. Asian $\mathbf{J}$ Androl. 2012, 14(3):409-414.

45. Mishra DK, Chen Z, Wu Y, Sarkissyan M, Koeffler HP, Vadgama JV: Global methylation pattern of genes in androgen-sensitive and androgen-independent prostate cancer cells. Mol Cancer Ther. 2010, 9(1):33-45.

46. Alimirah F, Chen J, Basrawala Z, Xin H, Choubey D: DU-145 and PC-3 human prostate cancer cell lines express androgen receptor: implications for the androgen receptor functions and regulation. FEBS Lett. 2006, 580(9):2294-2300.

47. Besson A, Dowdy SF, Roberts JM: CDK inhibitors: cell cycle regulators and beyond. Dev Cell. 2008, 14(2):159-169.

48. Boregowda RK, Appaiah HN, Karunakumar M, Parameshwariah S, Avadani G, Sunila S, Banerjee S: Development and validation of H11B2C2 monoclonal 
antibody-reactive hyaluronic acid binding protein: overexpression of HABP during human tumor progression. Tumour Biol. 2013, 34(1):597-608.

49. Williamson EA, Dadmanesh F, Koeffler HP: BRCA1 transactivates the cyclindependent kinase inhibitor p27(Kip1). Oncogene. 2002, 21(20):3199-3206.

50. Somasundaram K, Zhang H, Zeng YX, Houvras Y, Peng Y, Wu GS, Licht JD, Weber BL, El-Deiry WS: Arrest of the cell cycle by the tumour-suppressor BRCA1 requires the CDK-inhibitor p21WAF1/CiP1. Nature. 1997, 389(6647):187-190.

51. Klein HL: The consequences of Rad51 overexpression for normal and tumor cells. DNA Repair (Amst). 2008, 7(5):686-693.

52. Qidwai MT, Jamal F, Singh D, Sharma RK: Factors modifying transcriptional regulation of signaling genes have putative role in tumor development and progression in humans. Med Hypotheses. 2012, 79(6):805-812.

53. Thacker J: The RAD51 gene family, genetic instability and cancer. Cancer Lett. 2005, 219(2):125-135.

54. Marchong MN, Yurkowski C, Ma C, Spencer C, Pajovic S, Gallie BL: Cdh11 acts as a tumor suppressor in a murine retinoblastoma model by facilitating tumor cell death. PLoS Genet. 2010, 6(4):e1000923.

55. Li L, Ying J, Li H, Zhang Y, Shu X, Fan Y, Tan J, Cao Y, Tsao SW, Srivastava G, Chan AT, Tao Q: The human cadherin 11 is a pro-apoptotic tumor suppressor modulating cell stemness through Wnt/beta-catenin signaling and silenced in common carcinomas. Oncogene. 2012, 31(34):3901-3912.

56. Fischer H, Salahshor S, Stenling R, Bjork J, Lindmark G, Iselius L, Rubio C, Lindblom A: COL11A1 in FAP polyps and in sporadic colorectal tumors. BMC Cancer. 2001, 1:17.

57. Carmona FJ, Villanueva A, Vidal A, Munoz C, Puertas S, Penin RM, Goma M, Lujambio A, Piulats JM, Mesia R, Sanchez-Cespedes M, Manos M, Condom E, Eccles SA, Esteller M: Epigenetic disruption of cadherin-11 in human cancer metastasis. J Pathol. 2012, 228(2):230-240.

58. Stanbrough M, Bubley GJ, Ross K, Golub TR, Rubin MA, Penning TM, Febbo PG, Balk SP: Increased expression of genes converting adrenal androgens to testosterone in androgen-independent prostate cancer. Cancer Res. 2006, 66(5):2815-2825.

59. Burns-Cox N, Avery NC, Gingell JC, Bailey AJ: Changes in collagen metabolism in prostate cancer: a host response that may alter progression. J Urol. 2001, 166(5):1698-1701.

60. Duarte AH, Colli S, Alves-Pereira JL, Martins MP, Sampaio FJ, Ramos CF: Collagen I and III and metalloproteinase gene and protein expression in prostate cancer in relation to Gleason score. Int Braz J Urol. 2012, 38(3):341-354; discussion 354-345.

61. Howard S, Deroo T, Fujita Y, Itasaki N: A positive role of cadherin in Wnt/betacatenin signalling during epithelial-mesenchymal transition. PLoS One. 2011, 6(8):e23899.

62. Loh YN, Hedditch EL, Baker LA, Jary E, Ward RL, Ford CE: The Wnt signalling pathway is upregulated in an in vitro model of acquired tamoxifen resistant breast cancer. BMC Cancer. 2013, 13:174. 
63. Jedinak A, Thyagarajan-Sahu A, Jiang J, Sliva D: Ganodermanontriol, a lanostanoid triterpene from Ganoderma lucidum, suppresses growth of colon cancer cells through ss-catenin signaling. Int J Oncol. 2011, 38(3):761-767.

64. Zhang L, Zhou F, Van Laar T, Zhang J, Van Dam H, Ten Dijke P: Fas-associated factor 1 antagonizes Wnt signaling by promoting beta-catenin degradation. Mol Biol Cell. 2011, 22(9):1617-1624.

65. Gewies A, Rokhlin OW, Cohen MB: Ceramide induces cell death in the human prostatic carcinoma cell lines PC3 and DU145 but does not seem to be involved in Fas-mediated apoptosis. Lab Invest. 2000, 80(5):671-676.

66. Lieu CW, Lee SS, Wang SY: The Effect of Ganoderma-Lucidum on Induction of Differentiation in Leukemic U937-Cells. Anticancer Res. 1992, 12(4):1211-1216.

67. Liao SF, Liang CH, Ho MY, Hsu TL, Tsai TI, Hsieh YS, Tsai CM, Li ST, Cheng YY, Tsao SM, Lin TY, Lin ZY, Yang WB, Ren CT, Lin KI, Khoo KH, Lin CH, Hsu $\mathrm{HY}$, Wu CY, Wong CH: Immunization of fucose-containing polysaccharides from Reishi mushroom induces antibodies to tumor-associated Globo H-series epitopes. Proceedings of the National Academy of Sciences of the United States of America. 2013, 110(34):13809-13814.

68. Sugar LM: Inflammation and prostate cancer. Can J Urol. 2006, 13 Suppl 1:46-47.

69. Grivennikov SI, Greten FR, Karin M: Immunity, inflammation, and cancer. Cell. 2010, 140(6):883-899.

70. Birbach A, Eisenbarth D, Kozakowski N, Ladenhauf E, Schmidt-Supprian M, Schmid JA: Persistent inflammation leads to proliferative neoplasia and loss of smooth muscle cells in a prostate tumor model. Neoplasia. 2011, 13(8):692-703.

71. De Marzo AM, Platz EA, Sutcliffe S, Xu J, Gronberg H, Drake CG, Nakai Y, Isaacs WB, Nelson WG: Inflammation in prostate carcinogenesis. Nat Rev Cancer. 2007, 7(4):256-269.

72. Lewis AM, Varghese $\mathrm{S}, \mathrm{Xu} \mathrm{H}$, Alexander HR: Interleukin-1 and cancer progression: the emerging role of interleukin-1 receptor antagonist as a novel therapeutic agent in cancer treatment. J Transl Med. 2006, 4:48.

73. Yang $\mathrm{G}, \mathrm{Xu} \mathrm{Y}$, Chen $\mathrm{X}, \mathrm{Hu}$ G: IFITM1 plays an essential role in the antiproliferative action of interferon-gamma. Oncogene. 2007, 26(4):594-603.

74. Van Moorselaar RJ, Van Stratum P, Borm G, Debruyne FM, Schalken JA: Differential antiproliferative activities of alpha- and gamma-interferon and tumor necrosis factor alone or in combinations against two prostate cancer xenografts transplanted in nude mice. The Prostate. 1991, 18(4):331-344.

75. Schwartz JL, Shajahan AN, Clarke R: The Role of Interferon Regulatory Factor-1 (IRF1) in Overcoming Antiestrogen Resistance in the Treatment of Breast Cancer. Int J Breast Cancer. 2011, 2011:912102.

76. Li YJ, Liu G, Li Y, Vecchiarelli-Federico LM, Liu JC, Zacksenhaus E, Shan SW, Yang BB, Li Q, Dash R, Fisher PB, Archer MC, Ben-David Y: mda-7/IL-24 Expression Inhibits Breast Cancer Through Up-regulation of Growth Arrest-Specific Gene 3 (gas3) and Disruption of beta1 Integrin Function. Mol Cancer Res. 2013.

77. Xu S, Oshima T, Imada T, Masuda M, Debnath B, Grande F, Garofalo A, Neamati N: Stabilization of MDA-7/IL-24 for colon cancer therapy. Cancer Lett. 2013. 
78. Hu Y, Park-Min KH, Yarilina A, Ivashkiv LB: Regulation of STAT pathways and IRF1 during human dendritic cell maturation by TNF-alpha and PGE2. J Leukoc Biol. 2008, 84(5):1353-1360.

79. Gebhardt C, Nemeth J, Angel P, Hess J: S100A8 and S100A9 in inflammation and cancer. Biochem Pharmacol. 2006, 72(11):1622-1631.

80. Kallberg E, Vogl T, Liberg D, Olsson A, Bjork P, Wikstrom P, Bergh A, Roth J, Ivars F, Leanderson T: S100A9 interaction with TLR4 promotes tumor growth. PLoS One. 2012, 7(3):e34207.

81. Grebhardt S, Veltkamp C, Strobel P, Mayer D: Hypoxia and HIF-1 increase S100A8 and S100A9 expression in prostate cancer. Int J Cancer. 2012, 131(12):2785-2794.

82. Manitz MP, Horst B, Seeliger S, Strey A, Skryabin BV, Gunzer M, Frings W, Schonlau F, Roth J, Sorg C, Nacken W: Loss of S100A9 (MRP14) results in reduced interleukin-8-induced $\mathrm{CD} 11 \mathrm{~b}$ surface expression, a polarized microfilament system, and diminished responsiveness to chemoattractants in vitro. Mol Cell Biol. 2003, 23(3):1034-1043.

83. Hong KJ, Dunn DM, Shen CL, Pence BC: Effects of Ganoderma lucidum on apoptotic and anti-inflammatory function in HT-29 human colonic carcinoma cells. Phytother Res. 2004, 18(9):768-770.

84. Joseph S, Sabulal B, George V, Antony KR, Janardhanan KK: Antitumor and antiinflammatory activities of polysaccharides isolated from Ganoderma lucidum. Acta Pharm. 2011, 61(3):335-342.

85. Lin JM, Lin CC, Chiu HF, Yang JJ, Lee SG: Evaluation of the anti-inflammatory and liver-protective effects of anoectochilus formosanus, ganoderma lucidum and gynostemma pentaphyllum in rats. Am J Chin Med. 1993, 21(1):59-69. 